\title{
Functional Gene and Metabolic Changes of Marine Microbial Populations Involved in Hydrocarbon Degradation Under Different Enrichment Conditions
}

\section{Bingkui Song}

Hebei University of Technology

\section{Zhongzhen Zhang}

Hebei University of Technology

Si Li ( $\square$ jackeikee@126.com )

Hebei University of Technology https://orcid.org/0000-0001-9138-3569

\section{Qitong Fu}

Hebei University of Technology

\section{Shuting Qi}

Hebei University of Technology

Liang Li

Hebei University of Technology

$\mathrm{Di} \mathrm{Mu}$

Hebei University of Technology

Aili Zhang

Hebei University of Technology

\section{Research Article}

Keywords: Marine microorganisms, Petroleum hydrocarbon degradation, Metatranscriptome, KEGG pathway enrichment analysis, Metabolic Pathway

Posted Date: April 27th, 2021

DOl: https://doi.org/10.21203/rs.3.rs-457199/v1

License: (c) (i) This work is licensed under a Creative Commons Attribution 4.0 International License.

Read Full License 


\section{Abstract}

In this study, seawater from the area of an oil extraction platform in Bohai Bay was subjected to experimental treatments with oil as the only carbon source to understand the transcriptional responses of seawater microbial populations to oil degradation treatments. Twelve enrichment conditions were used, and fluorescent in situ hybridization (FISH) along with metatranscriptomic analyses were used to understand functional changes within each treatment. RNA from the petroleum-degrading bacterial enrichments was extracted after cultivation and FISH was used to evaluate overall activity, while changes in gene expression among different culture conditions were analyzed based on eight hydrocarbon-specific gene probes and flow cytometry. Concomitantly, 1,066 metabolic pathways were identified as being expressed in the populations through RNA sequencing, metatranscriptomic analysis, and metabolic pathway enrichment analysis. The addition of oil led to the inhibition of carbohydrate metabolism and inositol phosphate metabolism, while also reducing extracellular signaling pathway transcription levels. When low- and high-nutrient conditions were compared, low-nutrient conditions inhibited taurine and hypotaurine metabolism in addition to inositol phosphate metabolism. Among oxygen-treated, carbon dioxide-treated, and air-treated conditions, oxygen-treated conditions inhibited taurine and hypotaurine metabolism but promoted galactose metabolism, while carbon dioxide-treated conditions promoted inositol phosphate metabolism. Overall, metabolic pathway expression and functional gene changes indicated that high-nutrient, oil-free, and aerobic culture conditions best promoted the growth and reproduction of marine microbial communities.

\section{Introduction}

Marine pollution caused by offshore oil exploitation is one of the most important challenges for modern environments. However, microbial oil degradation offers unique advantages for the prevention and treatment of offshore oil pollution due to the low cost of application, high efficiency of degradation activity, and minimal pollution risk [1, 2]. Dehydrogenation, hydroxylation, and hydroperoxidation activities by microorganisms lead to the breakdown of alkanes and aromatic hydrocarbons in petroleum that are then used in the tricarboxylic acid cycle, transforming the carbon to $\mathrm{CO}_{2}$ and water while simultaneously promoting energy conservation within microbial populations [3, 4]. Environmental variation can significantly impact the ability of microorganisms to degrade petroleum hydrocarbons, and these degradation efficiencies can greatly vary across environments. If environmental parameters inhibit the growth of petroleum hydrocarbon-degrading bacteria, petroleum hydrocarbon can indefinitely persist in environments [5]. Consequently, understanding the interactions of gene activities in petroleum degradation in an inter-specific, networked, and comprehensive framework is key for understanding the microbial degradation of petroleum.

Metatranscriptomics allows the investigation of gene transcription within natural samples, in addition to the transcription and regulation of genes under specific conditions and in the life cycles of a specific population, thereby providing a more comprehensive understanding of the degradation of petroleum hydrocarbons by microbial metabolic activities. For example, Kothari compared the cultivation of 
Acinetobacter venetianus RAG-1 on dodecane, dodecanol, and sodium acetate, observing that three genes were transcribed that were involved in alkane oxidation-alkMa, alkMb, and almA. Among these, alkMb exhibited the highest differential expression and may be involved in dodecane oxidation. Further comparison of the strain grown on sodium acetate medium led to the identification of 1,074 differentially expressed genes, of which 622 up-regulated genes were involved in alkane catabolism and stress response to alkanes [6]. Moreover, Hong observed that Achromobacter.sp. HZ01 can degrade anthracene, phenanthrene, pyrene, and n-alkanes, using polycyclic aromatic hydrocarbons as the sole carbon source after petroleum treatment of strain HZO1 for $16 \mathrm{~h}$. In addition, a total of 742 differentially expressed genes were identified from strain HZ01 by transcriptomic analysis, with most down-regulated genes being related to cell motility, sugar metabolism, and ribosomal proteins, while genes involved in fatty acid metabolic pathways, some monooxygenases, and dehydrogenases were up-regulated, and TCA cycle genes were inactive [7]. Johanne Aubé compared a contaminated mat exposed to chronic petroleum contamination and a reference mat by using metagenomic and metatranscriptomic approaches. $A B C$ transporters, two-component systems, and type IV secretion system-related genes were overabundant in the contaminated mats. Xenobiotic degradation metabolism was lesser in the metagenomes of both mats, and only the expression of genes involved in polycyclic aromatic hydrocarbon degradation was higher in the contaminated mat [8]. Thus, most previous studies have primarily focused on types of oildegrading bacteria and their associated genes, while investigations have been lacking regarding the comprehensive regulation of marine oil hydrocarbon-degrading bacteria under specific environmental conditions (e.g., those associated with offshore drilling platforms). Consequently, this study evaluated the metabolic pathways and gene regulation of natural marine bacterial communities involved in the degradation of petroleum hydrocarbons. In particular, we systematically evaluated community structures, degradation pathways, and metabolic gene networks involved in petroleum hydrocarbon metabolism in near offshore drilling platform waters. The overall goal of the study was to provide a theoretical foundation for the microbial treatment of oil-spill accidents in offshore drilling platforms.

\section{Materials And Methods}

\section{Experimental Materials and Sampling}

Seawater samples were collected near an oil drilling platform located at $38^{\circ} 26^{\prime} 31.7^{\prime \prime} \mathrm{N}, 118^{\circ} 24^{\prime} 45.2^{\prime \prime} \mathrm{W}$. Samples were divided into 13 equal portions, each of which comprised $50 \mathrm{~L}$. For 12 of them, different culture conditions comprising high- and low-nutrient conditions, different aeration conditions, and conditions with or without oil were used to evaluate differences in gene transcription among treatments; the rest one was set as control (named as ORI group; the condition was kept as same as of the sampled seawater around oil drilling platform). Different ventilation conditions: Every day in the morning and evening, the $50 \mathrm{~L}$ seawater of barrel of each different aeration group was ventilated for half an hour with a steel cylinder filled with $\mathrm{CO}_{2}, \mathrm{O}_{2}$, or air. All flow rates are controlled at $5 \mathrm{mg} \mathrm{L}^{-1}$. Detailed cultivation parameters are described in Table 1. 
On the 1st, 5th, 15th, and 20th day of such culture, the bacteria in the seawater were filtered with a glass sand filter device to a $0.45 \mu \mathrm{m}$ and then a $0.22 \mu \mathrm{m}$ filter membrane, respectively. Each filter membrane was enriched with bacteria from $1000 \mathrm{ml}$ of seawater. The filter membrane, after bacterial enrichment, was divided into different $50 \mathrm{ml}$ centrifuge tubes according to different samples, marked, and stored in a refrigerator at $-80^{\circ} \mathrm{C}$. Gene transcription was evaluated by extracting RNA samples of treatment cultures on the 20th day of cultivation.

\section{Experimental Methods}

\section{Fluorescence in Situ Hybridization (Fish) of Petroleum- Degrading Bacteria}

Phosphorus absorption in Alcanivorax borkumensis is regulated by the high-affinity $A B C$ transporter system that is composed of phoU-pstBACS and phoBR gene expression products through the Pit transport system in nutrient-rich environments (> $20 \mathrm{mM} \mathrm{Pi}$ ). The znuA gene of Alcanivorax borkumensis is a periplasmic $\mathrm{Zn}^{2+}$ binding protein that is related to the high-affinity ATP-binding $\mathrm{ZnuABC}$ transport protein from E. coli [9]. In addition, phoB encodes positive regulators of the $E$. coli phosphor-regulator (including phoA, phoS, phoE, and ugpAB) [10]. Based on these previous studies, the following gene probes were used to evaluate gene transcription in the culture communities: znuA, phoB, nqrf, rubb, znub, moda, gltx, and ecta. The DNA of petroleum-degrading bacteria and performed primer verification were extracted. FISH was given on petroleum-degrading bacteria, and then used the American BD C6 flow cytometer (American BD Co., Tianjin Municipality, China) for detection.

\section{Metatranscriptomic Analyses}

RNA libraries were subjected to fragment screening prior to establishing the final RNA library. A qualitycontrolled library was then sequenced on the Illumina Hiseq high-throughput sequencing platform, and the raw data obtained from sequencing was used for subsequent transcriptomic analysis. Raw data was quality filtered to obtain clean data for evaluating taxonomic and functional differences between samples. The assembled sequencing data is available in the IMG/JGI (Integrated Microbial Genomes \& Microbiomes, DOE's Joint Genome Institute, USA) database (GOLD Analysis Project IDs are, ORI: Ga0439915, OOL: Ga0439914, OOH: Ga0439913, ONL: Ga0439912, ONH: Ga0439911, COL: Ga0439910, COH: Ga0439909, CNL: Ga0439908, CNH: Ga0439504, AOL: Ga0439503, AOH: Ga0439502, ANL: Ga0439501, ANH: Ga0439470). The abbreviations mean specific transcriptomes from certain conditions: $\mathrm{ORI}$, marine bacteria, directly from seawater, origin; OOL, marine bacteria, cultured with oxygen, oil(petroleum), and low nutrient content; $\mathrm{OOH}$, oxygen, oil(petroleum), and high nutrient content; $\mathrm{ONL}$, oxygen, no oil(petroleum), and low nutrient content; $\mathrm{ONH}$, oxygen, no oil(petroleum), and high nutrient content; $\mathrm{COL}$, carbon dioxide, oil(petroleum), and low nutrient content; $\mathrm{COH}$, carbon dioxide, oil(petroleum), and high nutrient content; $\mathrm{CNL}$, carbon dioxide, no oil(petroleum), and low nutrient content; $\mathrm{CNH}$, carbon dioxide, no oil(petroleum), and high nutrient content; $A O L$, air, oil(petroleum), and low nutrient content; $\mathrm{AOH}$, air, oil(petroleum), and high nutrient content; ANL, air, no oil(petroleum), and low nutrient content; $\mathrm{ANH}$, air, no oil(petroleum), and high nutrient content. 
BLAST (The Basic Local Alignment Search Tool) alignment (e value threshold of $\leq 1 \mathrm{e}-5$ for positive hits) of the quality filtered data against the NCBI non-redundant (NR) protein database was conducted. The lowest common ancestor (LCA) classification algorithm implemented in MEGAN (Metagenome Analyser) [11] was used to assign taxonomic classifications based on alignments, since each sequence might have multiple alignment results. Specifically, the taxonomic classification based on the first branch served as the species annotation for the sequence in question. Relative abundances of the ten most abundant classes are shown in the results, with the largest relative abundances in each sample shown and the remaining taxa being grouped as "Others".

Functional annotation of the quality filtered data was conducted using BLAST alignment of protein sequences against the assembled transcriptomic and protein annotation databases. Since multiple results could arise from each sequence alignment, the alignment results of each sequence were screened by calculating the alignment coverage ratio of each gene based on the reference and query lengths (i.e., the BLAST coverage ratio; $B C R$ ) to ensure that the BCR of the reference and query in each alignment exceeded $40 \%$. The corresponding functional annotation information was then compiled from the databases.

\section{Analysis of Metabolic Pathways}

Digital gene expression (DGE) profiling was used to compare the expression differences between the transcriptomic responses of this study's communities against that of transcriptome directly from marine environment. Metabolic pathway enrichment analysis based on KEGG pathways was then conducted in Pathview (a package in $\mathrm{R}$ ) to investigate differences in metabolic pathway representation of differentially expressed genes under different conditions, in addition to identifying potential regulatory mechanisms of functional genes.

\section{Results}

\section{Changes in Fluorescence Intensity of Petroleum-Degrading Bacteria under Different Culture Conditions}

The fluorescence intensities of cultures under high- and low-nutrient conditions with and without oil amendment are shown in Figs. 1 and 2, respectively. In the presence of oil and oxygen, the genes 3 (znuA), $7(\mathrm{~g} / \mathrm{tX})$, and $8(e c t A)$ exhibited higher fluorescence intensity on the 10th day of culture under high-nutrient conditions than under low-nutrient conditions. In conditions with oil and carbon dioxide supplementation, the fluorescence intensity of gene 3 (znuA) was higher under high-nutrient conditions than under lownutrient conditions on the 15th day of culture. When supplemented with oil and oxygen, the fluorescence intensity of gene $6(\bmod A)$ was higher under high-nutrient conditions than under low-nutrient conditions on the 20th day of culture. In non-oil amended, air-treated conditions, the fluorescence intensity of gene 2 (phoB) was higher under high-nutrient conditions than under low-nutrient conditions on the 15th day of culture. The non-oil amended and oxygen-treated condition cultures exhibited a higher fluorescence 
intensity of gene $2(p h o B)$ under high-nutrient conditions than under low-nutrient conditions on the 10th day of culture. In addition, the non-oil amended and oxygen-treated condition cultures exhibited a higher fluorescence intensity of gene $6(\bmod A)$ on the 20th day of culture under high-nutrient conditions than under low-nutrient conditions.

\section{The Metabolic Pathways of Marine Microbial Communities under Different Culture Conditions}

\section{Taxonomic Composition of Enrichment Cultures}

The abundances of the ten most abundant organisms significantly increased in comparison with the original seawater sample community composition (Fig. 3). In particular, the ten most abundant organisms (at the class level) were: $\gamma$-Proteobacteria, Saccharomyces, a-Proteobacteria, Flavobacteria, Actinomycetes, $\varepsilon$-Proteobacteria, $\delta$-Proteobacteria, $\beta$-Proteobacteria, Bacteroides, and Eurotium.

\section{Variation in Functional Gene Composition Within Metabolic Pathways under Different Culture Conditions}

The logarithmic ratios of the 20 most up-regulated (Table 2) and 20 most down-regulated (Table 3) differentially expressed genes within metabolic pathways under all conditions were specifically evaluated. The three most up-regulated protein encoding genes among all culture conditionsencoded 1) heat shock 70 kda proteins under $\mathrm{COL}$ vs ORI conditions, 2) heat shock 70 kda proteins under $\mathrm{COL}$ vs AOL conditions, and 3) superoxide dismutases within the Fe-Mn family under CNL vs ANL conditions. The three most down-regulated functional genes among all culture conditions were genes encoding 1) glutathione peroxidases under $\mathrm{OOL}$ vs $\mathrm{AOL}$ conditions, 2) elongation factor $1 \mathrm{a}$-like proteins under CNL vs ANL conditions, and 3) GMP synthetases (glutamine hydrolysis) under $\mathrm{CNH}$ vs ANH conditions.

\section{The Number of Metabolic Pathways under Different Culture Conditions}

A total of 1,066 metabolic pathway maps were obtained under when comparing culture conditions (Table 4). The four culture condition comparisons of $\mathrm{CNL}$ vs $\mathrm{CNH}, \mathrm{CNH}$ vs $\mathrm{ANH}, \mathrm{COH}$ vs $\mathrm{CNH}$, and $\mathrm{CNH}$ vs ORI exhibited the most pathways mapped. In addition, the ANL vs ANH and ONH vs ANH comparisons also exhibited numerous metabolic pathways.

\section{Analysis of Functional Gene Metabolic Pathway Transcription under Different Culture Conditions}


Different culture conditions with clearly different gene transcription profiles in metabolic pathways were selected for further evaluation. Comparisons between low- and high-nutrient conditions under air-treated and non-oil amended conditions (ANL vs ANH) are shown in Figs. 4 and 5, respectively. Glutamate decarboxylase (K01580), Y-glutamyl transpeptidase (K00681), and glutamate dehydrogenase (K00260) encoding genes were down-regulated in the taurine and hypotaurine metabolic regulation pathways (Fig. 4). Further, genes encoding inositol-1-phosphate synthase (K01858), phosphatidylinositol 4-kinase A (K00888), 1-phosphatidylinositol-3-phosphate 5-kinase (K00921), malonate-semialdehyde dehydrogenase (K00140) and triose phosphate isomerase (K01803) were down-regulated within the inositol phosphate metabolic pathway (Fig. 5).

Gene transcriptionn differences between carbon dioxide-treated and air-treated cultures under non-oil amended and high-nutrient conditions ( $\mathrm{CNH}$ vs $\mathrm{ANH}$ ) are shown in Fig. 6. Genes encoding galactokinase (K00849), hexokinase (K00844), and 6-phosphofructokinase 1 (K00850) were up-regulated in the galactose metabolic pathway. In contrast, genes encoding UTP-glucose-1-phosphate uridylyltransferase (K00963), glucose 4-epimerase (K01784), glutathione phosphate (K01835), maltose amylase (K12047), and other genes were down-regulated in the galactose metabolic pathway.

The gene transcription profile comparisons between oxygen-treated and air-treated cultures under non-oil amended and high-nutrient conditions ( $\mathrm{ONH}$ vs $\mathrm{ANH}$ ) are shown in Figs. 7 and 8, respectively. Genes encoding glucose 4-epimerase (K01784), glutathione phosphate (K01835), and maltose amylase (K12047) were up-regulated in the galactose metabolic pathway (Fig. 7). In addition, genes encoding glutamate decarboxylase (K01580) and y-glutamyl transpeptidase (K00681) were down-regulated in the taurine and hypotaurine metabolic pathways (Fig. 8). In contrast, genes encoding proteins like cysteine dioxygenase (K00456) and glutamate dehydrogenase (K00260) were up-regulated in the taurine and hypotaurine metabolic pathway.

Comparisons between carbon dioxide-treated and oxygen-treated conditions under oil amended and highnutrient conditions ( $\mathrm{COH}$ vs $\mathrm{OOH}$ ) are shown in Fig. 9. Genes encoding inositol-1-phosphate synthase (K01858) and phosphatidylinositol 4-kinase A (K00888) were up-regulated in the inositol phosphate metabolic pathway, while genes encoding malonate-semialdehyde dehydrogenase (K00140) and triose phosphate isomerase (K01803) were down-regulated in the inositol phosphate metabolic pathway.

Comparisons between the oil amended and non-oil amended conditions with carbon dioxide-treatment and high-nutrient conditions ( $\mathrm{COH}$ vs $\mathrm{CNH}$ ) are shown in Figs. 10 and 11. Genes encoding proteins, including sorbose reductase (K17742) and triose phosphate isomerase (K01803), were up-regulated in the fructose and mannose metabolic pathways (Fig. 10). In contrast, genes encoding hexokinase (K00844), mannose-1-phosphate guanylyltransferase (K00966), mannose-6-phosphate isomerase (K01809), 6phosphate fructose-2-kinase (K00900), 6-phosphate fructokinase 1 (K00850), fructose-bisphosphate aldolase (K01623), dihydroxyacetone kinase (K00863), and 6-bisphosphatase I (K03841) were downregulated in the fructose and mannose metabolic pathways. Genes encoding inositol-1-phosphate synthase (K01858), phosphatidylinositol 4-kinase A (K00888), 1-phosphatidylinositol-4-phosphate 5- 
kinase (K00889), phosphatidylinositol alcohol 3-kinase (K00914), 1-phosphatidylinositol-3-phosphate 5kinase (K00921), inositol oxygenase (K00469), malonate-semialdehyde dehydrogenase (K00140), and other genes were down-regulated in the inositol phosphate metabolic pathway (Fig. 11). In contrast, the triose phosphate isomerase (K01803) gene was up-regulated in the inositol phosphate metabolic pathway.

\section{Discussion}

\section{Analysis of Optimal Culture Conditions}

The optimal or sub-optimal nature of culture conditions can significantly effect gene expression and subsequent hybridization patterns [12]. Consequently, we compared changes in the fluorescence intensities of petroleum-degrading bacteria based on the hybridization with various probes under 12 culture conditions. The fluorescence intensities of cells under oxygen-treated conditions were the highest, indicating that oxygen-treatment conditions provided the most favorable culture environment for aerobic bacteria and therefore greater gene transcription hybridization. In addition, high-nutrient conditions provide adequate nutrient levels for cell growth, leading to greater levels of genes being expressed under high-nutrient conditions than in low-nutrient conditions.

\section{Metabolic Pathway Analysis}

\section{Analysis of Pathways Differentially Expressed under ANL vs ANH Conditions}

The metabolism of taurine and hypotaurine is primarily involved in the synthesis of taurine, hypotaurine, and their derivatives. Taurine and hypotaurine are antioxidants that protect cells from toxic oxidants [13]. Glutamate decarboxylase (K01580) catalyzes the transformation of 3-sulfinyl-L-alanine to hypotaurine, but also catalyzes the transformation of L-cysteine to taurine (Fig. 4) [14]. Thus, decreased nutrient concentrations will inhibit the activity of glutamate decarboxylase, resulting in less hypotaurine and taurine production. $\gamma$-glutamyl transpeptidase (K00681) catalyzes the transfer of $y$-glutamyl to other amino acids and peptides, while also catalyzing the formation of 5-glutamyl-taurine from taurine within this metabolic pathway [15]. Decreased nutrient concentrations inhibited the activity of $\mathrm{Y}$-glutamyl transpeptidase, likely leading to decreased end products. Glutamate dehydrogenase (K00260) catalyzes the reversible conversion of 2-oxoglutarate and L-glutamate [16] and decreased nutrient concentrations inhibited the activity of glutamate dehydrogenase when treated with air.

Metabolism of inositol phosphate is used to synthesize inositol phosphate (Fig. 5) that can be used as a second messenger for a variety of extracellular signals [17]. Inositol-1-phosphate synthase (K01858) catalyzes the conversion of D-glucose-6-phosphate to 1L-inositol-1-phosphate, with an intermediate product of 1D-inositol-3-phosphate [18]. When nutrient concentrations were lowered, the activity of 
inositol-1-phosphate synthase was inhibited, thereby reducing 1D-inositol-3-phosphate concentrations. Phosphatidylinositol 4-kinase A (K00888) catalyzes the conversion of Ptdlns into 4-phosphate Ptdlns [19] and decreased nutrient concentrations inhibited the activity of phosphatidylinositol 4-kinase $A$, therefore likely reducing product levels. 1-phosphatidylinositol-3-phosphate 5-kinase (K00921) catalyzes the conversion of 3-phosphate Ptdlns into Ptdlns-3, 5-P(2) [20], and lowered nutrient concentrations inhibited 1-phosphatidylinositol-3-phosphate 5-kinase activity, thereby likely resulting in decreased product levels. Malonate-semialdehyde dehydrogenase (K00140) catalyzes the oxidation of malonate semialdehyde (MSA) to acetyl-CoA [21]. The lower nutrient concentration treatment led to the inhibition of malonatesemialdehyde dehydrogenase activity. Triose phosphate isomerase (K01803) regulates the rapid balancing of dihydroxyacetone phosphate and glyceraldehyde-3-phosphate produced by aldolase during glycolysis [22], and decreased nutrient concentrations led to inhibition of its activity.

In summary, decreased nutrient concentrations inhibited the metabolic pathways of taurine and hypotaurine, thereby likely reducing the production of taurine and hypotaurine, and potentially enhancing the impact of harmful oxidants on cells. At the same time, these decrease also inhibit the metabolism of inositol phosphate and reduce the synthesis of inositol phosphate, potentially leading to losses of extracellular signaling and inhibiting cell growth and metabolism. Consequently, these results indicate that bacteria require sufficient nutrient levels to secure their own growth and reproduction requirements.

\section{Analysis Of Metabolic Pathways Differentially Expressed under $\mathrm{CNH}$ vs ANH Conditions}

Galactose metabolism involves the conversion of polysaccharides into monosaccharides like galactose and glucose. Galactose also exhibits a strong inhibitory effect on cell growth [23]. Galactokinase (K00849) catalyzes the conversion of a-D-galactose into galactose 1-phosphate (Fig. 6) [24]. The carbon dioxide-treated condition in the $\mathrm{CNH}$ and $\mathrm{ANH}$ treatments led to the enhancement of galactokinase activity, leading to increased levels of galactose 1-phosphate. UTP-glucose-1-phosphate uridylyltransferase (K00963) catalyzes the synthesis of UDP-glucose from glucose-1-phosphate and UTP [25]. However, in the carbon dioxide vs air treatment with high nutrients, the carbon dioxide-treatment conditions reduced the activity of the transferase. Glucose 4-epimerase (K01784) catalyzes the mutual conversion of UDP-galactose and UDP-glucose [26]. Compared with air-treated conditions, carbon dioxide treatment inhibited the activity of the epimerase and likely reduced the conversion efficiency of the above reaction. In addition, glutathione phosphate (K01835) is a necessary enzyme for the mutual conversion of glucose 1-phosphate and glucose 6-phosphate [27]. Likewise, carbon dioxide treatment inhibited the activity of glutathione phosphate, thereby likely reducing the transformation efficiency of this reaction as well. Hexokinase (K00844) phosphorylates glucose, catalyzing the conversion of glucose to glucose 6phosphate [28]. The carbon dioxide treatment increased the activity of hexokinase compared to the airtreated conditions, thereby increasing the efficiency of glucose phosphorylation. Maltose amylase (K12047) converts glucan derived from starch decomposition into glucose [29]. When comparing the $\mathrm{CNH}$ and $\mathrm{ANH}$ conditions, the carbon dioxide-treated conditions inhibited the activity of maltogenic amylase, thereby likely leading to reduced levels of glucose production. 6-phosphofructokinase 1 (K00850) 
catalyzes the conversion of 6-phosphate fructose to 1,6-diphosphate [30]. Carbon dioxide treatment also enhanced the activity of 6-phosphofructokinase 1 in the $\mathrm{CNH}$ vs ANH comparisons, likely leading to increased conversion efficiency of the above product.

Overall, changes of enzyme activity in the $\mathrm{CNH}$ vs ANH conditions led to increased galactose content, thereby inhibiting cell growth, with bacteria likely growing better in air-treated conditions.

\section{Analysis of Metabolic Pathways Differentially Expressed under $\mathrm{ONH}$ vs ANH Conditions}

Galactose metabolism converts polysaccharides into monosaccharides like galactose and glucose (Fig. 7). Glucose 4-epimerase (K01784) catalyzes the mutual conversion of UDP-galactose and UDPglucose [26]. Oxygen treatment enhanced the isomerase activity compared to the air-treated conditions and thus, likely the overall conversion efficiency of this reaction. Glutathione phosphate (K01835) is an enzyme necessary for the mutual conversion of glucose 1-phosphate and glucose 6-phosphate [27]. The oxygen-treatment in the $\mathrm{ONH}$ vs $\mathrm{ANH}$ treatment apparently enhanced the activity of glutathione phosphate, which would lead to increased transformation efficiency of the above reaction. Maltose amylase (K12047) converts glucan derived from starch decomposition into glucose [29], and oxygen treatment enhances the activity of maltogenic amylase and thus, the likely production of glucose when comparing the $\mathrm{ONH}$ and $\mathrm{ANH}$ conditions.

Cysteine dioxygenase (K00456) sulfonates and oxidizes cysteine to cysteine sulfinic acid (Fig. 8) [31] and catalyzes the transformation of cysteine to 3-sulfinyl-L-alanine in this metabolic pathway. Oxygen addition increased the expression of cysteine dioxygenase compared with the air-ventilated condition. Glutamate decarboxylase (K01580) catalyzes the transformation of 3-sulfinyl-L-alanine to hypotaurine, but also catalyzes the transformation of L-cysteine to taurine [14]. Oxygen inhibited the activity of glutamate decarboxylase in the $\mathrm{ONH}$ vs $\mathrm{ANH}$ comparison, which would result in a decrease in the products hypotaurine and taurine. $Y$-glutamyl transpeptidase (K00681) can catalyze the transfer of $Y^{-}$ glutamyl to other amino acids and peptides, while catalyzing the formation of 5-glutamyl-taurine from taurine via this metabolic pathway [15]. Oxygen also inhibited the activity of $\gamma$-glutamyl transpeptidase, which would result in decreased reaction products. Glutamate dehydrogenase (K00260) can catalyze the reversible conversion of 2-oxoglutarate and L-glutamate [16] and its activity was up-regulated by oxygen treatment compared with the air-ventilated condition.

In conclusion, oxygen-treatment conditions compared to air-treatment conditions promote the metabolism of galactose, accelerate polysaccharide degradation efficiency and provide additional nutrients for bacterial growth. Thus, bacteria would exhibit better survival under oxygen treatment conditions. At the same time, oxygen will reduce the production of taurine and hypotaurine compared with air-treatment conditions. Thus, taurine and hypotaurine content will increase under air-treated conditions, potentially due to the presence of harmful oxidants present in air relative to exposure to only oxygen. Increasing taurine and hypotaurine content will inhibit the effect of harmful oxidants on cells. 


\section{Analysis of Metabolic Pathways Differentially Expressed under $\mathrm{COH}$ vs $\mathrm{OOH}$ Conditions}

Inositol-1-phosphate synthase (K01858) catalyzes the conversion of D-glucose-6-phosphate into 1Linositol-1-phosphate, forming the intermediate product of 1D-inositol-3-phosphate (Fig. 9) [18]. Compared with oxygen-treated condition, carbon dioxide treatment enhances the activity of inositol-1-phosphate synthase, which in turn increases 1D-inositol-3-phosphate levels. Phosphatidylinositol 4-kinase A (K00888) catalyzes the conversion of Ptdlns to 4-phosphate Ptdlns [19]. The $\mathrm{COH}$ treatment enhanced the activity of phosphatidylinositol 4-kinase $\mathrm{A}$ compared to the $\mathrm{OOH}$ condition and would lead to increased product levels. Malonate-semialdehyde dehydrogenase (K00140) catalyzes the oxidation of malonate semialdehyde (MSA) to acetyl-CoA [21]. Compared with oxygen-treated conditions, carbon dioxide inhibited the activity of malonate-semialdehyde dehydrogenase. Triose phosphate isomerase (K01803) regulates the rapid balancing of dihydroxyacetone phosphate and glyceraldehyde-3-phosphate that are produced by aldolase in the glycolysis process [22]. Compared with the $\mathrm{OOH}$ condition, $\mathrm{COH}$ conditions will inhibit the activity of triose phosphate isomerase.

In conclusion, the $\mathrm{COH}$ condition increased the synthesis capacity for inositol phosphate compared to $\mathrm{OOH}$ conditions, which resulted in increased extracellular signal transmission. Thus, carbon dioxide treatments would lead to unfavorable factors against bacterial growth and reproduction, with cells needing to transmit increasing levels of signals to regulate growth and metabolism.

\section{Analysis of Metabolic Pathways Differentially Expressed under $\mathrm{COH}$ vs $\mathrm{CNH}$ Conditions}

A series of enzymes are needed to transform monosaccharides like L-sorbose and D-allose into fructose, mannose, and glucose. Sorbose reductase (K17742) converts L-sorbose into D-sorbitol (Fig. 10) [32]. When oil was added as the carbon source, sorbose reductase activity is enhanced and the conversion rate likely increases. Hexokinase (K00844) phosphorylates glucose [28] and catalyzes fructose and mannose conversion to fructose 6-phosphate and mannose 6-phosphate, respectively. When oil was added as the carbon source, hexokinase activity was inhibited. Mannose-1-phosphate guanylyltransferase (K00966) catalyzes the reaction of mannose-1-phosphate and GTP to produce GDP mannose [33]. When oil was added as the carbon source, transferase activity was inhibited. Mannose-6-phosphate isomerase (K01809) catalyzes the mutual conversion of mannose 6-phosphate (Man-6-P) and fructose 6-phosphate (Fru-6-P) [34], and adding oil as the carbon source inhibited the activity of the isomerase, thereby restricting this mutual conversion activity. Fructose 2,6-diphosphate is a signal molecule that controls glycolysis, and 6-phosphate fructose-2-kinase (K00900) catalyzes the synthesis of fructose 6-phosphate into fructose 2,6-diphosphate [35]. When oil was added as the carbon source, 6-phosphofructose-2-kinase activity was inhibited. Fructose-1,6-bisphosphatase I (K03841) catalyzes the conversion of fructose 1,6diphosphate into fructose 6-phosphate [36]. When oil was added as the carbon source, the activity of fructose-1,6-bisphosphatase I was inhibited and the conversion to fructose 6-phosphate would have thus been reduced. 6-phosphofructokinase 1 (K00850) catalyzes the conversion of 6-phosphate fructose to 
1,6-diphosphate [30], but adding oil as the carbon source inhibited the activity of 6-phosphofructokinase 1. Fructose-bisphosphate aldolase (K01623) catalyzes the condensation of glucose-3-phosphate and dihydroxyacetone phosphate to form fructose 1,6-diphosphate [37]. Under the oil addition treatment, the activity of fructose-bisphosphate aldolase was inhibited, resulting in a likely decrease of fructose 1,6diphosphate products. Triose phosphate isomerase (K01803) regulates the rapid balancing of dihydroxyacetone phosphate and glyceraldehyde-3-phosphate produced by aldolase during glycolysis [22]. When oil was added as the carbon source, the activity of triose phosphate isomerase increased and the mutual conversion rate likely increased. Dihydroxyacetone kinase (K00863) phosphorylates fructosederived glyceraldehyde to produce glyceraldehyde-3-phosphate [38]. When oil was added as the carbon source, the activity of dihydroxyacetone kinase was inhibited, likely leading to a decrease in product formation.

Inositol-1-phosphate synthase (K01858) catalyzes the conversion of D-glucose-6-phosphate to 1L-inositol1-phosphate (Fig. 11), with the intermediate product being 1D-inositol-3-phosphate [18]. When oil was added as the carbon source, inositol-1-phosphate synthase activity was inhibited, thereby reducing the amount of 1D-inositol-3-phosphate that was produced. Phosphatidylinositol 4-kinase A (K00888) catalyzes the conversion of phosphatidylinositol (Ptdlns) into 4-phosphate Ptdlns [19]. Upon oil addition treatment, inhibited activity of phosphatidylinositol 4-kinase A would result in decreased product levels. 1phosphatidylinositol-4-phosphate 5-kinase (K00889) catalyzes the synthesis of 4-phosphate Ptdlns to 4,5bisphosphate PtdIns [39], and decreased nutrient concentrations inhibited the activity of 1phosphatidylinositol-4-phosphate 5-kinase. Phosphatidylinositol 3-kinase (K00914) catalyzes the transformation of Ptdlns to produce 3-phosphate Ptdlns [40], while the addition of oil as a carbon source inhibited the activity of phosphatidylinositol 3-kinase, thereby likely decreasing the levels of the product Ptdlns. 1-phosphatidylinositol-3-phosphate 5-kinase (K00921) catalyzes the conversion of 3-phosphate Ptdlns to Ptdlns-3,5-P(2) [20], and when oil was added as the carbon source, the activity of 1phosphatidylinositol-3-phosphate 5-kinase was inhibited, likely resulting in a decrease in its product. Malonate-semialdehyde dehydrogenase (K00140) catalyzes the oxidation of malonate semialdehyde (MSA) to acetyl-CoA [21]. When oil was added as the carbon source, the activity of malonatesemialdehyde dehydrogenase was inhibited. Triose phosphate isomerase (K01803) regulates the rapid balancing of dihydroxyacetone phosphate and glyceraldehyde-3-phosphate that are produced by aldolase during glycolysis [22]. When oil was added as a carbon source, the activity of triose phosphate isomerase was enhanced. Inositol oxygenase (K00469) is the only mechanism to catabolize inositol, wherein it catalyzes the cleavage of the inositol ring and transfers an oxygen atom to it [41]. This metabolism catalyzes the decomposition of inositol into glucuronate and the addition of oil as a carbon source inhibited the activity of inositol oxygenase, thereby likely reducing the decomposition efficiency of inositol.

Overall, the addition of oil as a carbon source led to the inhibition of fructose and mannose metabolism and the concomitant decrease in fructose and mannose production. Thus, the ability of populations to consume sugar for survival will be lessened under such conditions, and oil will instead be degraded for energy conservation. Concomitantly, the addition of oil as the carbon source will inhibit the metabolism of 
inositol phosphate and reduce its synthesis, leading to the loss of extracellular signaling, thereby inhibiting cell growth along with metabolism and other activities. Thus, the addition of oil results in counterproductive effects on the growth and reproduction of bacteria.

\section{Conclusions}

This study investigated the transcriptomic responses of seawater microbial communities that were collected from near a drilling platform in Bohai Bay in response to varying enrichment incubations. We specifically evaluated the transcription of enzyme-encoding genes and their related metabolic pathways that were associated with hydrocarbon metabolism and energy conservation. The enrichment culture cells and their metabolic activities exhibited differential adaptations to the enrichment conditions and exhibited different responses to aerobic and anaerobic culture conditions. Metabolic pathway transcription and functional gene analyses suggested that high-nutrient, oil-free, and aerobic culture conditions largely promoted the growth and reproduction of marine microbial populations. Understanding how these microorganisms may degrade hydrocarbons is an important focus for helping to remediate oil spill ecological problems. These results can help develop remediation protocols for oil spills.

\section{Declarations}

\section{Acknowledgment}

We thank LetPub (www.letpub.com) for its linguistic assistance and scientific consultation during the preparation of this manuscript.

\section{Funding Information}

The study was supported by Natural Science Foundation of Hebei Province, China (Grant No. D2020202004), National Natural Science Foundation of China Youth Project (Grant No. 31801948), National Natural Science Foundation of China (Grant No. 51474084 and Grant No. 21978065), Key R\&D Projects in Hebei Province (Grant No. 19226505D), Tianjin Science and Technology Committee (No.18ZXRHSF00270).

\section{Conflict of Interest Statement}

The authors declare that they have no conflict of interest.

\section{Declaration of Competing Interest}

The authors declare that they have no known competing financial interests or personal relationships that could have appeared to influence the work reported in this paper.

\section{References}


1. Pawl T, Edward J (1991) Hydrocarbon contaminated soils and groundwater. Lewis Publishers INC, Lewis

2. Delille D, Basseres A, Dessommes A (1998) Effectiveness of bioremediation for oil-polluted Antarctic seawater. Polar Biology 19:237-241. https://doi.org/10.1007/s003000050240

3. Das N, Chandran P (2011) Microbial Degradation of Petroleum Hydrocarbon Contaminants: An Overview. Biotechnology Research International. https://doi.org/10.4061/2011/941810

4. Sekelsky, A.M., Shreve, G.S. (1999) Kinetic model of biosurfactant-enhanced hexadecane biodegradation by Pseudomonas aeruginosa. Biotechnology and bioengineering.63,401-409. https://doi.org/10.1002/(SICI)1097-0290(19990520)63:4<401::AID-BIT3>3.0.C0;2-S

5. Li L, Zhang L, Zhang Y (2001) Research overview of petroleum hydrocarbon-degrading bacteria. Microbiology China 28.5:89-92

6. Kothari A, Charrier M, Wu YW et al (2016) Transcriptomic analysis of the highly efficient oil-degrading bacterium Acinetobacter venetianus RAG-1 reveals genes important in dodecane uptake and utilization. FEMS Microbiol Lett 363(20):fnw224. https://doi.org/10.1093/femsle/fnw224

7. Hong Y, Deng M, Xu X et al (2016) Characterization of the transcriptome of Achromobacter sp. HZ01 with the outstanding hydrocarbon-degrading ability. Gene 584(2):185-194.

https://doi.org/10.1016/j.gene.2016.02.032

8. Aubé J, Senin P, Bonin P et al (2020) Meta-omics Provides Insights into the Impact of Hydrocarbon Contamination on Microbial Mat Functioning. Microb Ecol 80:286-295. https://doi.org/10.1007/s00248-020-01493-x

9. Liliya A, Yatsunyk J, Allen,Easton,Lydia R, Kim,Stacy (2008) Structure and metal binding properties of ZnuA, a periplasmic zinc transporter from Escherichia coli. J Biol Inorg Chem 13:271-288. https://doi.org/10.1007/s00775-007-0320-0

10. Makino. K, Shinagawa $H$, Amemura M, Nakata A (1986) Nucleotide sequence of the phoB gene, the positive regulatory gene for the phosphate regulon of Escherichia coli K-12. J Journal of Molecular Biology 190:37-44. https://doi.org/10.1016/0022-2836(86)90073-2

11. Huson DH et al (2007) MEGAN analysis of metagenomic data. Genome Res 17(3):377-386

12. He Y, Chen $C$, Huang $B(2018)$ The regulation of bacterial small non-coding RNA on gene expression under environmental stress. Journal of Molecular Diagnosis Therapy 10:125-131,144. https://doi.org/10.3969/j.issn.1674-6929.2018.02.011

13. L. D B (1990) Taurine and hypotaurine content of human leukocytes. Journal of leukocyte biology. 2. https://doi.org/10.1111/j.1365-2141.1990.tb07825.x

14. Weinstein CL, Griffith OWJMiE (1987) Cysteinesulfinate decarboxylase. Methods in Enzymology 143,404. https://doi.org/ 10.1016/0166-0934(87)90050-4

15. Toshihiro O, Hideyuki S, Kei W, Hidehiko K, F.J.P.o.t.N.A.o.S.o.t.U.S.o.A. Keiichi (2006) Crystal structures of $\mathrm{Y}$-glutamyltranspeptidase from Escherichia coli, a key enzyme in glutathione metabolism, and its reaction intermediate. Proceedings of the National Academy of Sciences. 103 (17),6471-6476. https://doi.org/10.1073/pnas.0511020103 
16. Srivastava HS, Singh RPJP (1987) Role and regulation of L -glutamate dehydrogenase activity in higher plants. $26,597-610$

17. Mishra J, U.S.J.B.J., Bhalla (2002) Simulations of Inositol Phosphate Metabolism and Its Interaction with InsP-Mediated Calcium Release. 83,1298-1316. https://doi.org/10.1016/S0006-3495(02)739015

18. Majumder AL, Johnson MD, A.J.B.B.A. S, Henry (1997) 1L - myo -inositol-1-phosphate synthase. Biochim Biophys Acta 1348:245-256

19. Balla A, Balla TJTiCB (2006) Phosphatidylinositol 4-kinases: old enzymes with emerging functions. Trends in cell biology 16:351-361. https://doi.org/10.1016/j.tcb.2006.05.003

20. Diego S, Ikonomov OC, Robert D, SJJ.o.BC Assia (2002) Phosphatidylinositol 5-phosphate biosynthesis is linked to PIKfyve and is involved in osmotic response pathway in mammalian cells. Journal of Biological Chemistry Journal of Biological Chemistry 277:47276-47284. https://doi.org/10.1074/jbc.M207576200

21. Claire SC, Guy BJBJ (2006) Mechanistic characterization of the MSDH (methylmalonate semialdehyde dehydrogenase) from Bacillus subtilis. Biochemical Journal 395:107-115. https://doi.org/10.1042/BJ20051525

22. Ferene O, Judit O, Judit OJIL (2006) Triosephosphate isomerase deficiency: facts and doubts. IUBMB Life 58:703-715. https://doi.org/10.1080/15216540601115960

23. Aki K (2007) Different effects of galactose and mannose on cell proliferation and intracellular soluble sugar levels in Vigna angularis suspension cultures. Journal of plant research. 6. https://doi.org/10.1007/s10265-007-0117-9

24. Holden HM, Thoden J, Timson D, Reece R (2004) Galactokinase: Structure, function and role in type II galactosemia. Cellular and Molecular Life Sciences CMLS. https://doi.org/10.1007/s00018-0044160-6

25. Thoden JB, Holden HMJPS (2010) Active site geometry of glucose-1-phosphate uridylyltransferase. Protein Sci 16:1379-1388. https://doi.org/10.1110/ps.072864707

26. Thoden JB, Frey PA, Holden HM (1996) Molecular structure of the NADH/UDP-glucose abortive complex of UDP-galactose 4-epimerase from Escherichia coli: implications for the catalytic mechanism. Biochemistry 35:5137-5144. https://doi.org/10.1021/bi9601114

27. Lu M., Kleckner N (1994) Molecular cloning and characterization of the pgm gene encoding phosphoglucomutase of Escherichia coli. J Bacteriol 176:5847-5851.

https://doi.org/10.1111/j.1365-2672.1994.tb03084.x

28. John W E (2003) Isozymes of mammalian hexokinase: structure, subcellular localization and metabolic function. The Journal of experimental biology Pt 12. https://doi.org/10.1242/jeb.00241

29. Maricela DS, Roberto QC, Avery SE, Chacko SK, Li-Ke Y, Amy Hui-Mei L, Zi-Hua A, Hamaker BR, Nichols BL (2013) Maltase-glucoamylase modulates gluconeogenesis and sucrase-isomaltase dominates starch digestion glucogenesis. Journal of Pediatric Gastroenterology Nutrition 57:704-712. https://doi.org/10.1097/MPG.0b013e3182a27438 
30. Currie MA, Merino F, Skarina T, Wong AHY, Singer A, Brown G, Savchenko A, Caniuguir A, Guixé V, A.F.J.J.o.BYakunin C (2009) ADP-dependent 6-Phosphofructokinase from Pyrococcus horikoshii OT3. J Biol Chem.284,22664-22671. https://doi.org/10.1074/jbc.M109.012401

31. Dominy JE, Simmons CR, Andrew KP, Gehring AM, Stipanuk MH (2006) Identification and characterization of bacterial cysteine dioxygenases: a new route of cysteine degradation for eubacteria. Journal of Bacteriology 188:5561-5569. https://doi.org/10.1128/JB.00291-06

32. Greenberg JR, Price NP, Oliver RP, Fred S, Elena RJY (2010) Candida albicans SOU1 encodes a sorbose reductase required for L-sorbose utilization. Yeast 22:957-969. https://doi.org/10.1002/yea.1282

33. Diez MDA, Demonte A, Giacomelli J, Garay S, Rodrígues D, Hofmann B, Hecht HJ, Guerrero SA, A.A.J.A.o.Mlglesias (2010) Functional characterization of GDP-mannose pyrophosphorylase from Leptospira interrogans serovar Copenhageni. Archives of Microbiology. 192,103. https://doi.org/10.1007/s00203-009-0534-3

34. Wenxia F, Xiaoying Y, Bin W, Hui Z, Haomiao O, Jia M, Cheng JJM (2009) Characterization of the Aspergillus fumigatus phosphomannose isomerase Pmi1 and its impact on cell wall synthesis and morphogenesis. Microbiology 155:3281-3293. https://doi.org/10.1099/mic.0.029975-0

35. Rider MH, Bertrand L, Vertommen D, Michels PA, Rousseau GG, Hue LJBJ (2004) 6-phosphofructo-2kinase/fructose-2,6-bisphosphatase: head-to-head with a bifunctional enzyme that controls glycolysis. Biochemical Journal 381(Pt 3):561-579. https://doi.org/10.1042/BJ20040752

36. Naeem R, Hiroyuki I, Tamotsu K, Toshiaki F, Haruyuki A, I.J.J.o.B.C. Tadayuki (2002) A novel candidate for the true fructose-1,6-bisphosphatase in archaea. Journal of Biological Chemistry. 277, 30649-30655. https://doi.org/10.1074/jbc.M202868200

37. Lorentzen E, Siebers B, Hensel R, Pohl EJBST (2004) Structure, function and evolution of the Archaeal class I fructose-1,6-bisphosphate aldolase. Biochemical society transactions. 32,259. https://doi.org/10.1042/BST0320259

38. Joaquim Rui R (2014) Bifunctional homodimeric triokinase/FMN cyclase: contribution of protein domains to the activities of the human enzyme and molecular dynamics simulation of domain movements. Journal of biological chemistry.15. https://doi.org/10.1074/jbc.M113.525626

39. Xie Z, Chang SM, Pennypacker SD, Liao EY, DDJ.M.B.o.t.C. Bikle (2009) Phosphatidylinositol-4phosphate 5-kinase 1alpha mediates extracellular calcium-induced keratinocyte differentiation. Molecular biology of the cell. 20,1695. https://doi.org/10.1091/mbc.E08-07-0756

40. Volinia S, Dhand,. R, Vanhaesebroeck B,., Macdougall LK, Stein,. R, Zvelebil MJ, Domin J.., Panaretou C, ., Waterfield MD (1995) ) A human phosphatidylinositol 3-kinase complex related to the yeast Vps34p-Vps15p protein sorting system. Embo Journal 14:3339-3348. https://doi.org/10.1002/j.1460-2075.1995.tb07340.x

41. Arner RJ, Prabhu KS, Thompson JT, Hildenbrandt GR, Liken AD, Reddy CC (2002) Myo-inositol oxygenase: molecular cloning and expression of a unique enzyme that oxidizes myo-inositol and dchiro-inositol. Biochemical Journal 360:313-320. https://doi.org/10.1042/bj3600313 


\section{Tables}

\section{Table 1}

Setting of cultivation conditions for response of microbial communities near offshore drilling platforms to conditional changes 


\begin{tabular}{|c|c|c|c|c|c|c|c|}
\hline \multirow{2}{*}{$\begin{array}{l}\text { Sample } \\
\text { codings }\end{array}$} & \multirow{2}{*}{$\begin{array}{l}\text { Sample } \\
\text { description } \\
\text { Sample } \\
\text { sources } \\
\text { and } \\
\text { processing, } \\
\text { time point } \\
\text { etc., } \\
\text { condition } \\
\text { types }\end{array}$} & \multicolumn{6}{|c|}{ Detailed cultivation parameters } \\
\hline & & $\begin{array}{l}\text { Oil } \\
\text { concentration }\end{array}$ & $\begin{array}{l}\mathrm{NO}_{3}^{-} \\
(\mathrm{mg} / \mathrm{l})\end{array}$ & 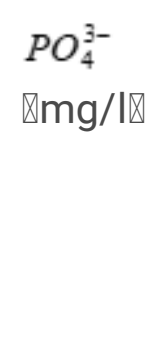 & $\begin{array}{c}\mathrm{NO}_{2}^{-} \\
\bigotimes \mathrm{mg} / \mathrm{I} \bigotimes\end{array}$ & $\begin{array}{l}\mathrm{pH} \\
\text { ( } \mathrm{CO}_{2} \text { causes } \\
\text { acidification })\end{array}$ & $\begin{array}{l}\text { Dissolved } \\
\text { oxygen } \\
\text { 『mg/l }\end{array}$ \\
\hline COL & $\begin{array}{l}\text { Marine } \\
\text { bacteria, } \\
\text { carbon } \\
\text { dioxide, oil, } \\
\text { low- } \\
\text { nutrient } \\
\text { culture }\end{array}$ & $1 \%$ & 13 & 182 & 0.03 & 6.13 & 2.2 \\
\hline $\mathrm{COH}$ & $\begin{array}{l}\text { Marine } \\
\text { bacteria, } \\
\text { carbon } \\
\text { dioxide, oil, } \\
\text { high- } \\
\text { nutrient } \\
\text { culture }\end{array}$ & $1 \%$ & 1300 & 785 & 87 & 6.18 & 1.7 \\
\hline CNL & $\begin{array}{l}\text { Marine } \\
\text { bacteria, } \\
\text { carbon } \\
\text { dioxide, } \\
\text { non-oil, } \\
\text { low- } \\
\text { nutrient } \\
\text { culture }\end{array}$ & $0 \%$ & 7 & 15 & 0.06 & 6.59 & 3.6 \\
\hline $\mathrm{CNH}$ & $\begin{array}{l}\text { Marine } \\
\text { bacteria, } \\
\text { carbon } \\
\text { dioxide, } \\
\text { non-oil, } \\
\text { high- } \\
\text { nutrient } \\
\text { culture }\end{array}$ & $0 \%$ & 180 & 1300 & 179 & 6.43 & 1.3 \\
\hline OOL & $\begin{array}{l}\text { Marine } \\
\text { bacteria, } \\
\text { oxygen, oil, } \\
\text { low- } \\
\text { nutrient } \\
\text { culture }\end{array}$ & $1 \%$ & 11 & 9 & 0.04 & 7.15 & 7.1 \\
\hline $\mathrm{OOH}$ & $\begin{array}{l}\text { Marine } \\
\text { bacteria, } \\
\text { oxygen, oil, } \\
\text { high- } \\
\text { nutrient } \\
\text { culture }\end{array}$ & $1 \%$ & 800 & 1640 & 297 & 6.9 & 7.6 \\
\hline
\end{tabular}




\begin{tabular}{|c|c|c|c|c|c|c|c|}
\hline ONL & $\begin{array}{l}\text { Marine } \\
\text { bacteria, } \\
\text { oxygen, } \\
\text { non-oil, } \\
\text { low- } \\
\text { nutrient } \\
\text { culture }\end{array}$ & $0 \%$ & 14 & 20 & 0.05 & 8.17 & 4.6 \\
\hline $\mathrm{ONH}$ & $\begin{array}{l}\text { Marine } \\
\text { bacteria, } \\
\text { oxygen, } \\
\text { non-oil, } \\
\text { high- } \\
\text { nutrient } \\
\text { culture }\end{array}$ & $0 \%$ & 270 & 1155 & 237 & 6.96 & 6 \\
\hline $\mathrm{AOL}$ & $\begin{array}{l}\text { Marine } \\
\text { bacteria, } \\
\text { air, oil, low- } \\
\text { nutrient } \\
\text { culture }\end{array}$ & $1 \%$ & 6 & 73 & 0.05 & 6.86 & 1.4 \\
\hline $\mathrm{AOH}$ & $\begin{array}{l}\text { Marine } \\
\text { bacteria, } \\
\text { air, oil, } \\
\text { high- } \\
\text { nutrient } \\
\text { culture }\end{array}$ & $1 \%$ & 750 & 2600 & 161 & 7.51 & 2.9 \\
\hline ANL & $\begin{array}{l}\text { Marine } \\
\text { bacteria, } \\
\text { air, non-oil, } \\
\text { low- } \\
\text { nutrient } \\
\text { culture }\end{array}$ & $0 \%$ & 5 & 37 & 0.06 & 8.02 & 3.8 \\
\hline ANH & $\begin{array}{l}\text { Marine } \\
\text { bacteria, } \\
\text { air, non-oil, } \\
\text { high- } \\
\text { nutrient } \\
\text { culture }\end{array}$ & $0 \%$ & 860 & 1300 & 253 & 7.06 & 3 \\
\hline ORI & $\begin{array}{l}\text { Marine } \\
\text { bacteria, } \\
\text { directly } \\
\text { collected } \\
\text { from the } \\
\text { seawater } \\
\text { at drilling } \\
\text { platform, } \\
\text { original } \\
\text { point }\end{array}$ & $0 \%$ & 0.0279 & 0.00021 & 0.0279 & 8.21 & 3.6 \\
\hline
\end{tabular}




\section{Table 2}

The twenty most up-regulated genes in the transcriptomes of marine petroleum hydrocarbon-degrading bacterial populations under different enrichment conditions. 


\begin{tabular}{|c|c|c|c|c|c|}
\hline Rank & $\begin{array}{l}\text { Treatment } \\
\text { Comparison }\end{array}$ & Gene ID & $\begin{array}{l}\text { KEGG } \\
\text { Orthology } \\
\text { ID }\end{array}$ & Annotation & $\begin{array}{l}\log _{2} \\
\text { Fold } \\
\text { change }\end{array}$ \\
\hline 1 & COL vs ORI & CNHc25501_g1 & K09490 & Heat shock 70 kDa protein 5 & 17.351 \\
\hline 2 & COL vs AOL & CNHc25501_g1 & K09490 & Heat shock 70 kDa protein 5 & 16.69 \\
\hline 3 & CNL vs ANL & CNLc46456_g2 & K04564 & $\begin{array}{l}\text { Superoxide dismutase, Fe-Mn } \\
\text { family }\end{array}$ & 16.648 \\
\hline 4 & CNL vs ANL & CNLc46305_g2 & K00111 & $\begin{array}{l}\text { Glycerol-3-phosphate } \\
\text { dehydrogenase }\end{array}$ & 16.066 \\
\hline 5 & ONL vs ORI & ONLc108377_g1 & K13525 & $\begin{array}{l}\text { Transitional endoplasmic } \\
\text { reticulum ATPase }\end{array}$ & 15.879 \\
\hline 6 & COH vs ORI & ONHc38088_g7 & K01803 & $\begin{array}{l}\text { Triosephosphate isomerase } \\
\text { (TIM) }\end{array}$ & 15.41 \\
\hline 7 & COL vs AOL & CNLc46973_g1 & K14403 & $\begin{array}{l}\text { Cleavage and polyadenylation } \\
\text { specificity factor subunit } 3\end{array}$ & 15.325 \\
\hline 8 & COH vs ORI & OOHc45325_g1 & K03231 & Elongation factor 1 -alpha & 14.978 \\
\hline 9 & CNH vs ORI & CNHc25422_g5 & K01868 & Threonyl-tRNA synthetase & 14.919 \\
\hline 10 & CNL vs ANL & CNLc47032_g1 & K07513 & Acetyl-CoA acyltransferase 1 & 14.89 \\
\hline 11 & CNL vs ANL & CNLc46097_g1 & K14572 & Midasin & 14.856 \\
\hline 12 & CNL vs ANL & CNLc46329_g1 & K00432 & Glutathione peroxidase & 14.697 \\
\hline 13 & COL vs OOL & COLc132630_g1 & K11233 & $\begin{array}{l}\text { Osomolarity two-component } \\
\text { system, Response regulator } \\
\text { SSK1 }\end{array}$ & 14.638 \\
\hline 14 & COL vs AOL & COHc206826_g1 & K04079 & Molecular chaperone HtpG & 14.572 \\
\hline 15 & $\mathrm{OOL}$ vs $\mathrm{OOH}$ & OOLc165459_g4 & K08955 & ATP-dependent metalloprotease & 14.501 \\
\hline 16 & COL vs ORI & COHc206952_g2 & K04079 & Molecular chaperone HtpG & 14.479 \\
\hline 17 & $\mathrm{OOL}$ vs $\mathrm{OOH}$ & COHc205626_g3 & K14416 & $\begin{array}{l}\text { Elongation factor } 1 \text { a-like } \\
\text { protein }\end{array}$ & 14.414 \\
\hline 18 & $\mathrm{OOL}$ vs $\mathrm{OOH}$ & ONLc108377_g1 & K13525 & $\begin{array}{l}\text { Transitional endoplasmic } \\
\text { reticulum ATPase }\end{array}$ & 14.413 \\
\hline 19 & OOL vs OOH & OOLc167494_g5 & K14403 & $\begin{array}{l}\text { Cleavage and polyadenylation } \\
\text { specificity factor subunit } 3\end{array}$ & 14.373 \\
\hline 20 & COL vs ORI & COLc129759_g1 & K10901 & Bloom syndrome protein & 14.299 \\
\hline
\end{tabular}




\section{Table 3}

The twenty most down-regulated genes in the transcriptomes of marine petroleum hydrocarbondegrading bacterial populations under different enrichment conditions. 


\begin{tabular}{|c|c|c|c|c|c|}
\hline Rank & $\begin{array}{l}\text { Treatment } \\
\text { Comparison }\end{array}$ & Gene ID & $\begin{array}{l}\text { KEGG } \\
\text { Orthology } \\
\text { ID }\end{array}$ & Definition & $\begin{array}{l}\log _{2} \text { Fold } \\
\text { change }\end{array}$ \\
\hline 1 & OOL vs AOL & AOLc124810_g1 & K00432 & Glutathione peroxidase & -17.446 \\
\hline 2 & CNL vs ANL & ANLc85495_g1 & K14416 & $\begin{array}{l}\text { Elongation factor } 1 \text { alpha- } \\
\text { like protein }\end{array}$ & -15.481 \\
\hline 3 & $\mathrm{CNH}$ vs $\mathrm{ANH}$ & OOHc45443_g1 & K01951 & $\begin{array}{l}\text { GMP synthase (glutamine- } \\
\text { hydrolysing) }\end{array}$ & -15.469 \\
\hline 4 & $\mathrm{COH}$ vs $\mathrm{AOH}$ & ANHc41385_g1 & K14572 & Midasin & -15.288 \\
\hline 5 & $\mathrm{CNH}$ vs $\mathrm{ANH}$ & ANHc42565_g1 & K03781 & Catalase & -15.278 \\
\hline 6 & $\mathrm{COH}$ vs $\mathrm{CNH}$ & ANHc40531_g1 & K02145 & $\begin{array}{l}\text { V-type H+-transporting } \\
\text { ATPase subunit A }\end{array}$ & -15.076 \\
\hline 7 & CNL vs ANL & ANLc86683_g1 & K12818 & $\begin{array}{l}\text { ATP-dependent RNA } \\
\text { helicase DHX8/PRP22 }\end{array}$ & -14.911 \\
\hline 8 & CNL vs ANL & AOHc60780_g2 & K00326 & Cytochrome-b5 reductase & -14.879 \\
\hline 9 & CNL vs ANL & ANLc89125_g1 & K01810 & $\begin{array}{l}\text { Glucose-6-phosphate } \\
\text { isomerase }\end{array}$ & -14.795 \\
\hline 10 & $\mathrm{COH}$ vs $\mathrm{CNH}$ & CNHc11955_g1 & K09468 & $\begin{array}{l}\text { Zinc finger protein } \\
\text { MSN2/4 }\end{array}$ & -14.721 \\
\hline 11 & CNL vs ANL & ANLc89286_g1 & K08955 & $\begin{array}{l}\text { ATP-dependent } \\
\text { metalloprotease }\end{array}$ & -14.646 \\
\hline 12 & $\mathrm{COH}$ vs $\mathrm{CNH}$ & ONHc35651_g1 & K09580 & $\begin{array}{l}\text { Protein disulfide- } \\
\text { isomerase A1 }\end{array}$ & -14.411 \\
\hline 13 & $\mathrm{CNH}$ vs $\mathrm{ANH}$ & ANHc42678_g1 & K03106 & $\begin{array}{l}\text { Signal recognition particle } \\
\text { subunit SRP54 }\end{array}$ & -14.36 \\
\hline 14 & $\mathrm{COH}$ vs $\mathrm{AOH}$ & AOHc61941_g4 & K00966 & $\begin{array}{l}\text { Mannose-1-phosphate } \\
\text { guanylyltransferase }\end{array}$ & -14.353 \\
\hline 15 & $\mathrm{CNH}$ vs $\mathrm{ANH}$ & AOLc124685_g1 & K00762 & $\begin{array}{l}\text { Orotate } \\
\text { phosphoribosyltransferase }\end{array}$ & -14.308 \\
\hline 16 & CNL vs ONL & ONLc108377_g1 & K13525 & $\begin{array}{l}\text { Transitional endoplasmic } \\
\text { reticulum ATPase }\end{array}$ & -14.291 \\
\hline 17 & $\mathrm{CNH}$ vs $\mathrm{ANH}$ & AOHc61110_g1 & K08744 & $\begin{array}{l}\text { Cardiolipin synthase } \\
\text { (CMP-forming) }\end{array}$ & -14.29 \\
\hline 18 & $\mathrm{CNH}$ vs $\mathrm{ANH}$ & ANHc38916_g1 & K12818 & $\begin{array}{l}\text { ATP-dependent RNA } \\
\text { helicase DHX8/PRP22 }\end{array}$ & -14.252 \\
\hline 19 & $\mathrm{COH}$ vs $\mathrm{CNH}$ & ANHc40011_g1 & K10967 & $\begin{array}{l}\text { Alpha 1,2- } \\
\text { mannosyltransferase }\end{array}$ & -14.198 \\
\hline 20 & $\mathrm{COH}$ vs $\mathrm{CNH}$ & CNHc6836_g1 & K03252 & $\begin{array}{l}\text { Translation initiation } \\
\text { factor } 3 \text { subunit C }\end{array}$ & -14.184 \\
\hline
\end{tabular}




\section{Table 4}

Number of metabolic pathways mapped to the transcriptomes from different conditions.

\begin{tabular}{|llll|}
\hline Treatment Comparison & Pathways & Treatment Comparison & Pathways \\
\hline ANH vs ORI & 36 & COL vs AOL & 29 \\
\hline ANL vs ANH & 38 & COL vs CNL & 38 \\
\hline ANL vs ORI & 32 & COL vs COH & 32 \\
\hline AOL vs ORI & 32 & COL vs OOL & 30 \\
\hline CNH vs ANH & 48 & COL vs ORI & 30 \\
\hline CNH vs ONH & 36 & ONH vs ANH & 38 \\
\hline CNH vs ORI & 45 & ONH vs ORI & 31 \\
\hline CNL vs ANL & 39 & ONL vs ANL & 41 \\
\hline CNL vs CNH & 50 & ONL vs ORI & 35 \\
\hline CNL vs ONL & 35 & OOH vs AOH & 32 \\
\hline CNL vs ORI & 35 & OOH vs ORI & 29 \\
\hline COH vs AOH & 31 & OOL vs AOL & 35 \\
\hline COH vs CNH & 45 & OOL vs ONL & 33 \\
\hline COH vs OOH & 31 & OOL vs OOH & 32 \\
\hline COH vs ORI & 35 & OOL vs ORI & 33 \\
\hline
\end{tabular}

\section{Figures}




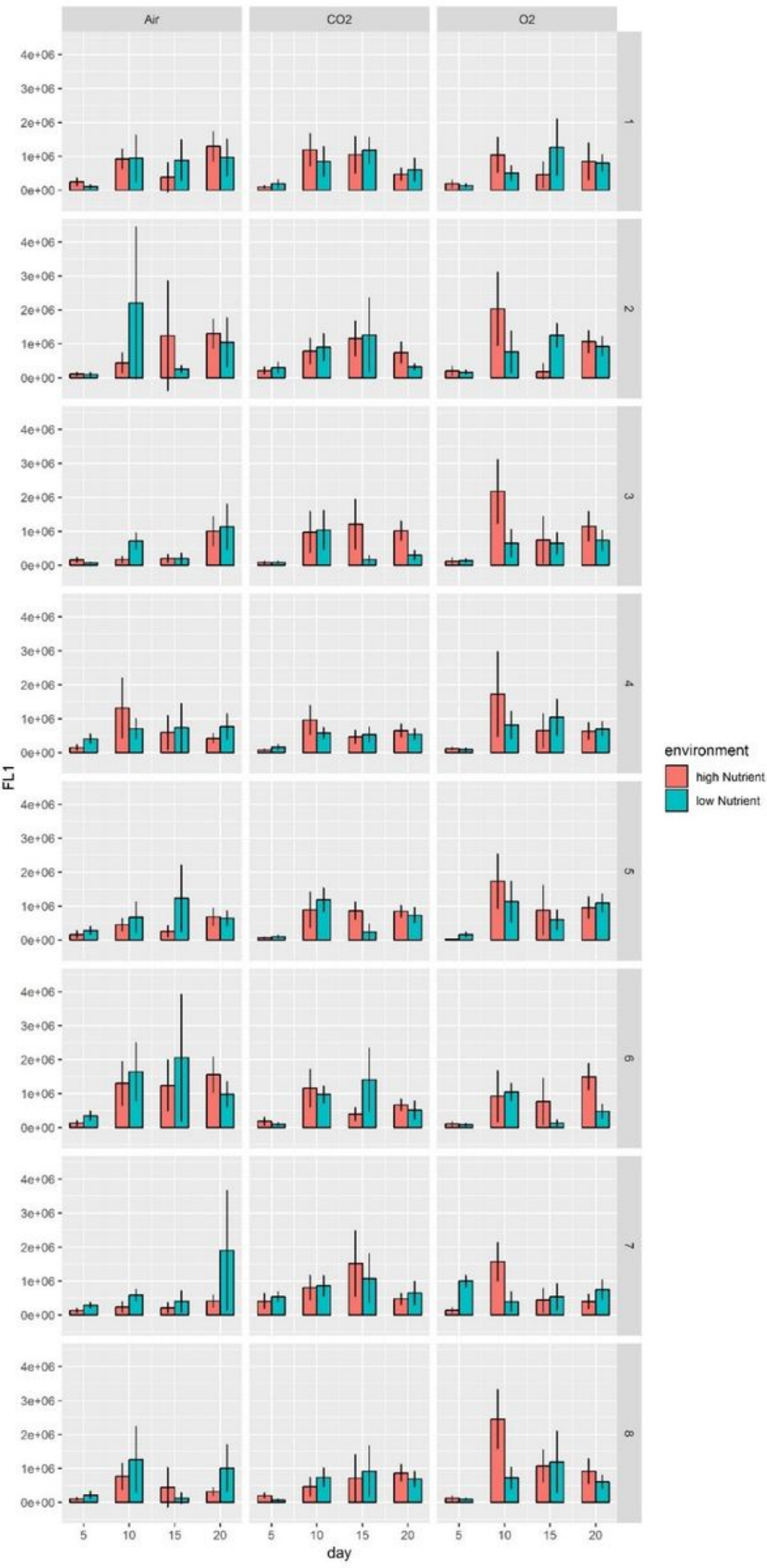

Figure 1

Comparisons of fluorescence intensities for eight probe hybridization activities of cells in the presence of oil under high- and low-nutrient conditions. The x-axis shows cultivation time, while the y-axis shows fluorescence intensity. The three treatments of air-ventilated, carbon dioxide-ventilated, and oxygenventilated conditions are shown as different vertical panels, while the eight horizontal sub-panels represent each of the eight gene probes. Red bars show values for high-nutrient conditions and blue bars 
show those for low-nutrient conditions. Columns show average fluorescence intensities, and the error bars represent the $95 \%$ confidence interval. Gene 1: znuA, gene 2: phoB, gene 3: nqrF, gene 4: rubB, gene 5 : znuB, gene 6: modA, gene 7: gltX, and gene 8: ectA.
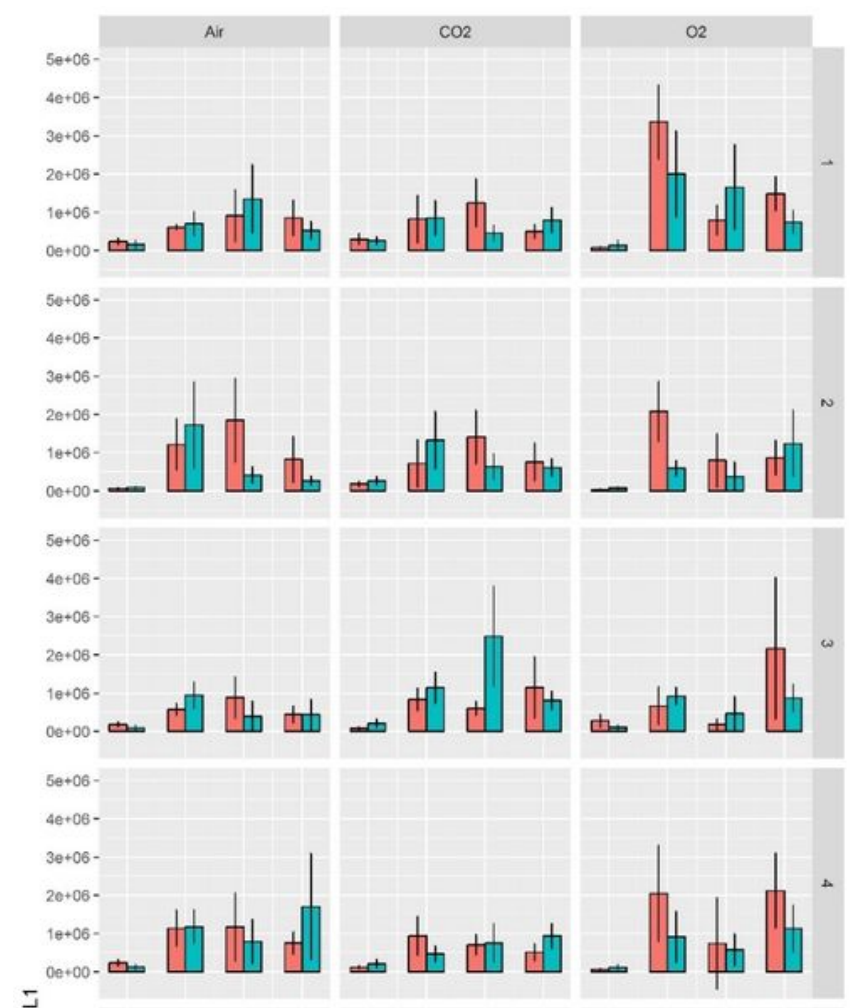

군

$x_{n \rightarrow \infty}$

nas.
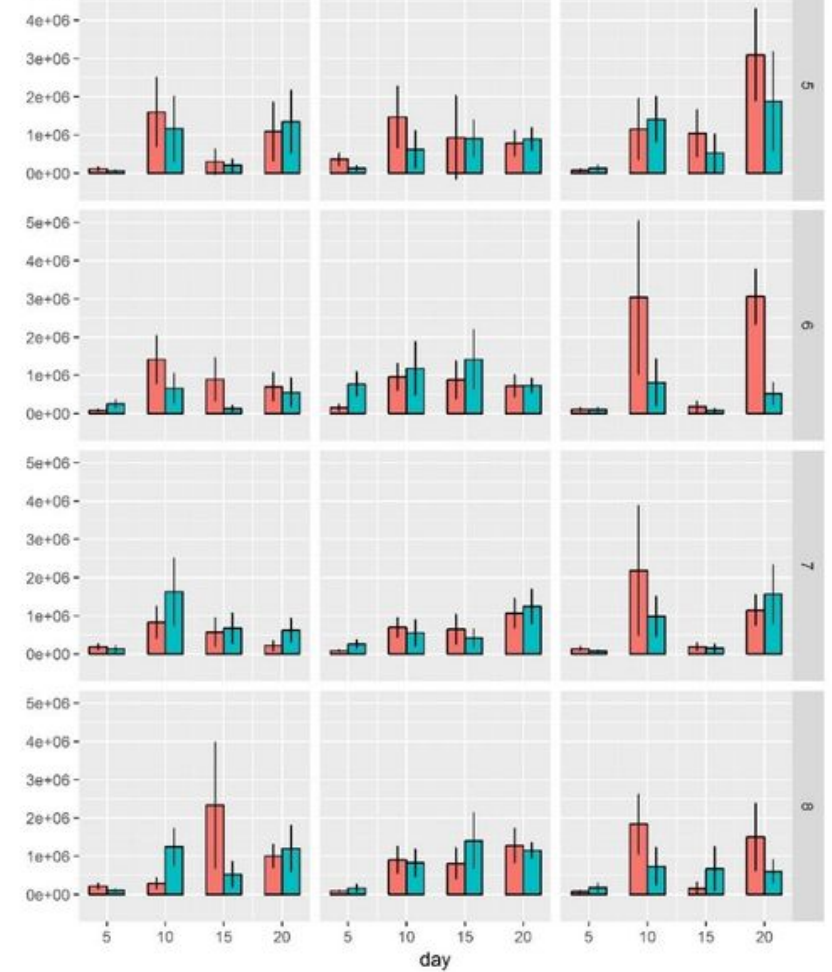

Figure 2

Comparisons of fluorescence intensities for eight probe hybridization activities of cells in the absence of oil under high- and low-nutrient conditions. The x-axis shows cultivation time, while the y-axis shows 
fluorescence intensity. The three treatments of air-ventilated, carbon dioxide-ventilated, and oxygenventilated conditions are shown as different vertical panels, while the eight horizontal sub-panels represent each of the eight gene probes. Red bars show values for high-nutrient conditions and blue bars show those for low-nutrient conditions. Columns show average fluorescence intensities, and the error bars represent the $95 \%$ confidence interval. Gene 1: znuA, gene 2: phoB, gene 3: nqrF, gene 4: rubB, gene 5: znuB, gene 6: modA, gene 7: gltX, and gene 8: ectA.

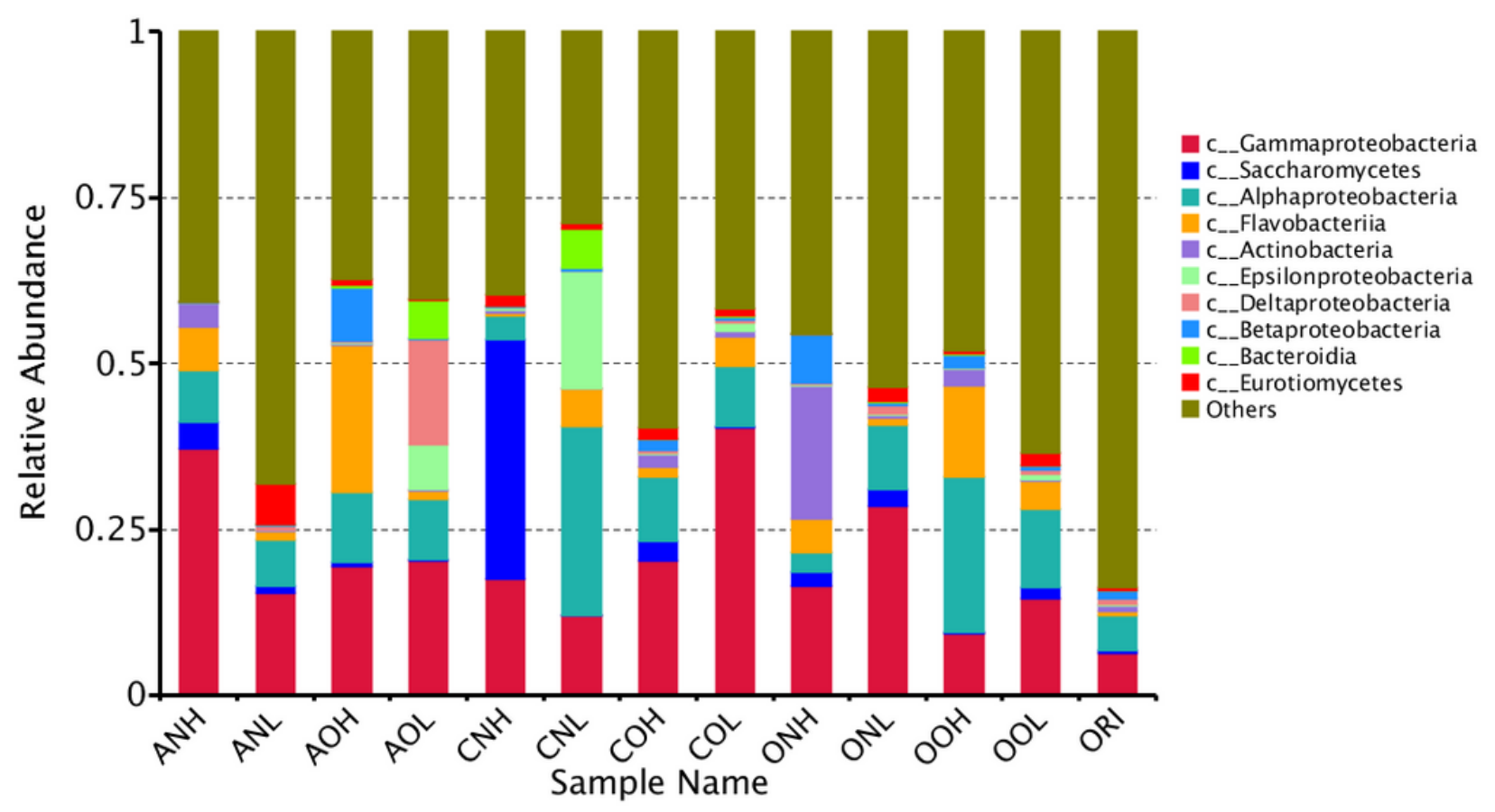

Figure 3

Taxonomic classifications of the culture communities based on the relative abundances of classes. Colors correspond to taxa indicated on the legend to the right and treatments are indicated at the bottom. 
TAURINE AND HYPOTAURINE METABOLISM
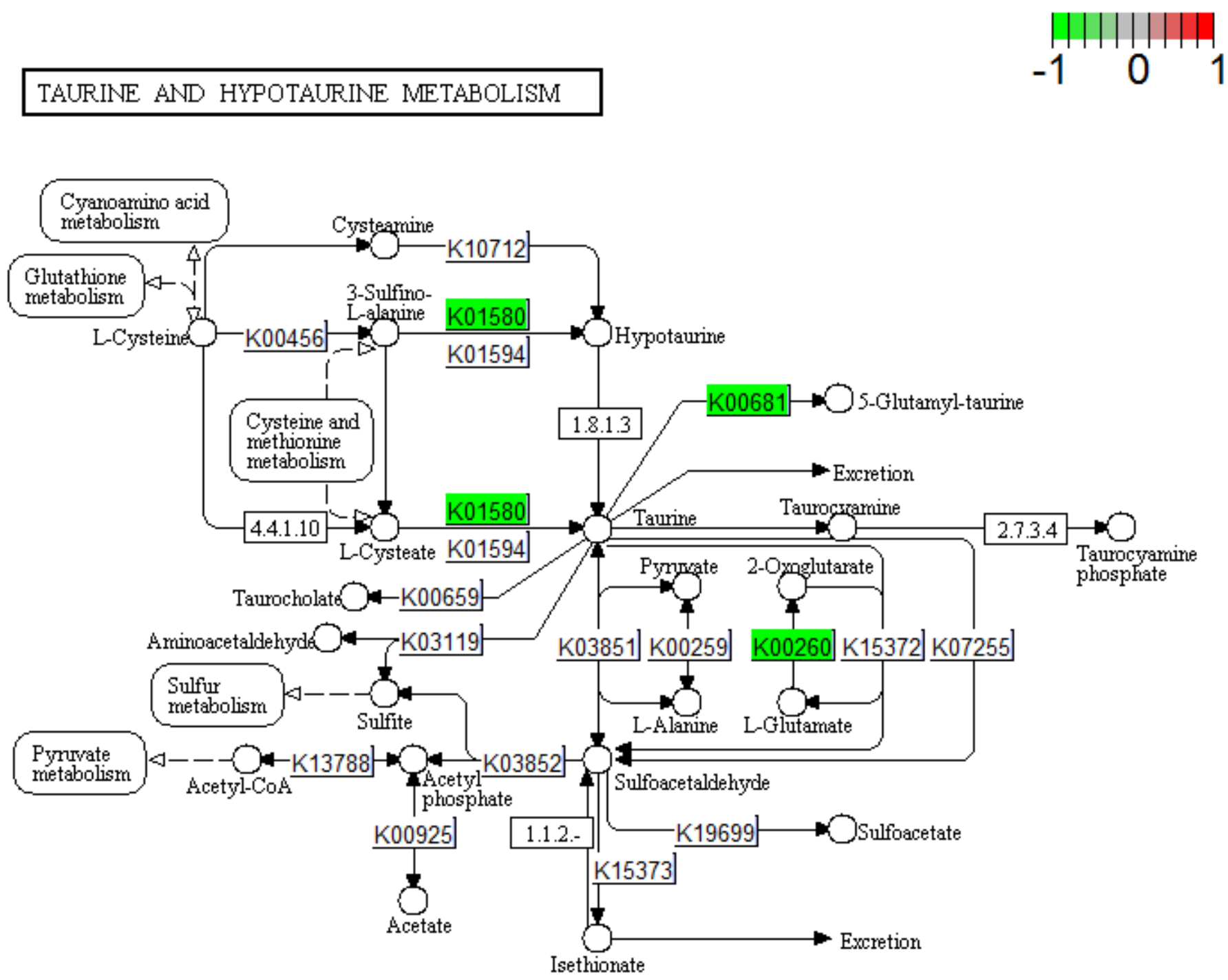

Data on KEGG graph

Rendered by Pathview

Figure 4

Taurine and hypotaurine metabolic pathways and differences in expression under the ANL vs ANH conditions. The color legend in the upper right corner indicates red values for level of gene upregulation and green for gene downregulation, as indicated for differentially expressed genes within the pathway map. 


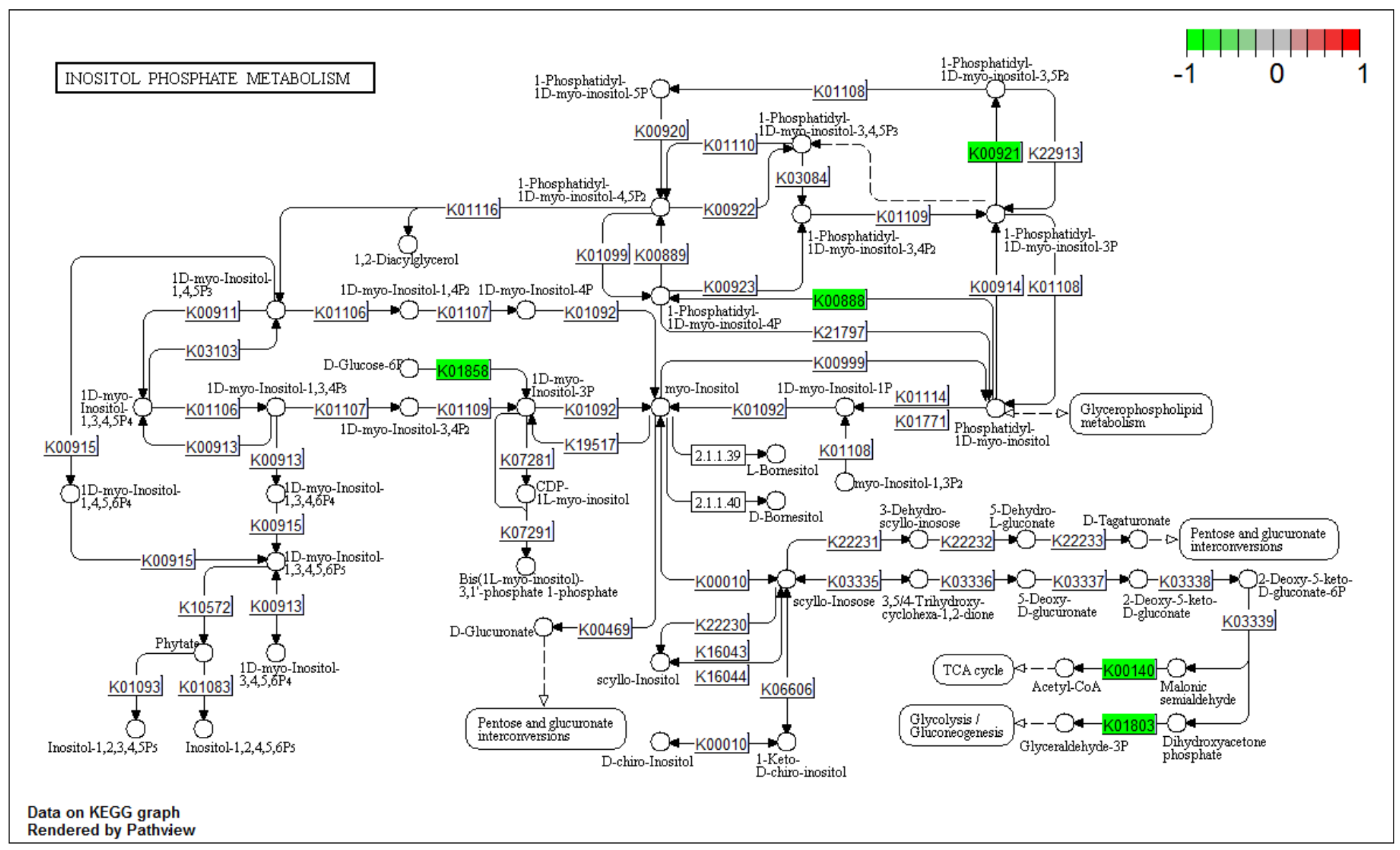

Figure 5

Inositol phosphate metabolic pathways and differences in expression under the ANL vs ANH conditions. The color legend in the upper right corner indicates red values for level of gene upregulation and green for gene downregulation, as indicated for differentially expressed genes within the pathway map. 


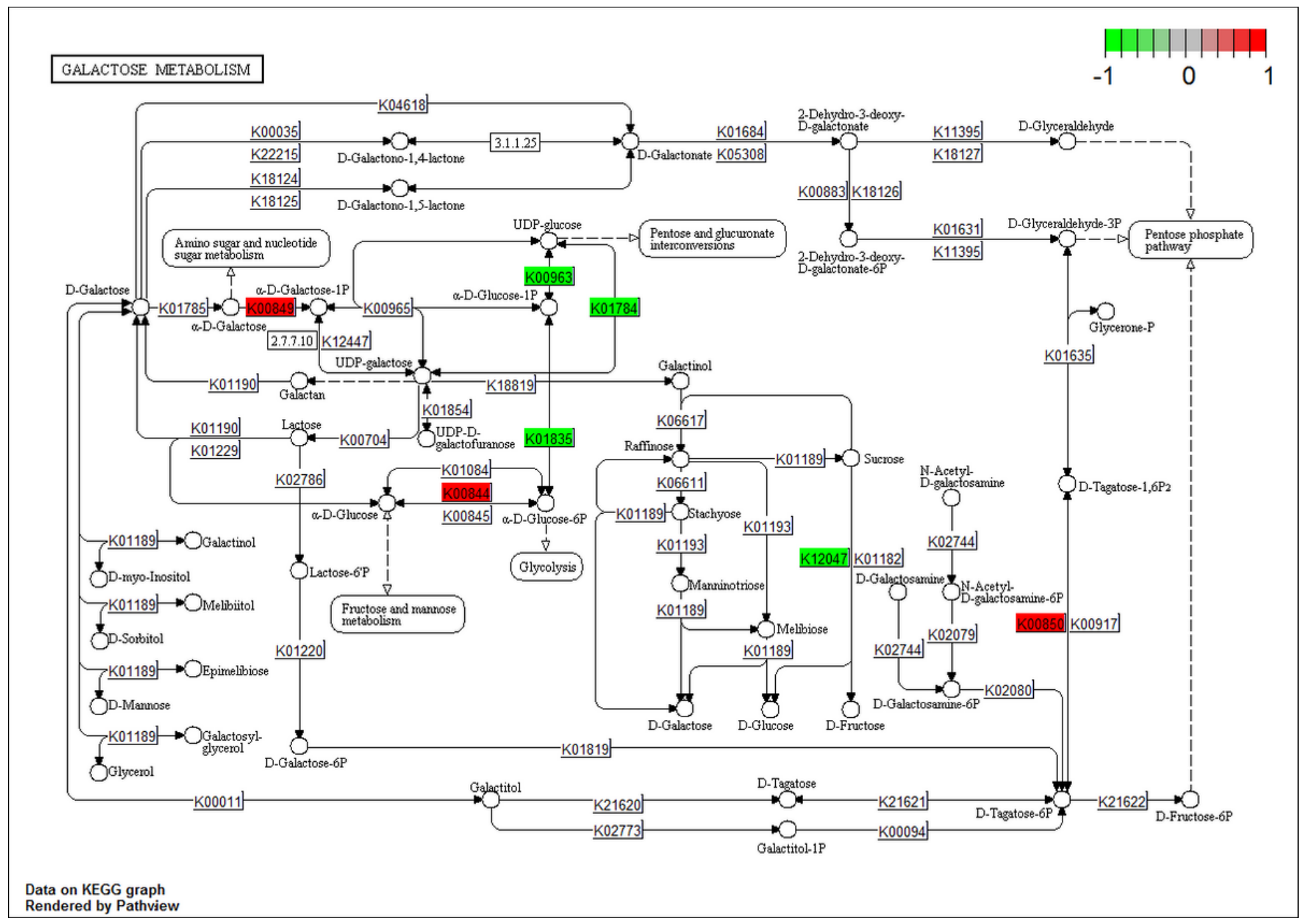

\section{Figure 6}

Galactose metabolic pathways and differences in expression under the $\mathrm{CNH}$ vs ANH conditions. The color legend in the upper right corner indicates red values for level of gene upregulation and green for gene downregulation, as indicated for differentially expressed genes within the pathway map. 


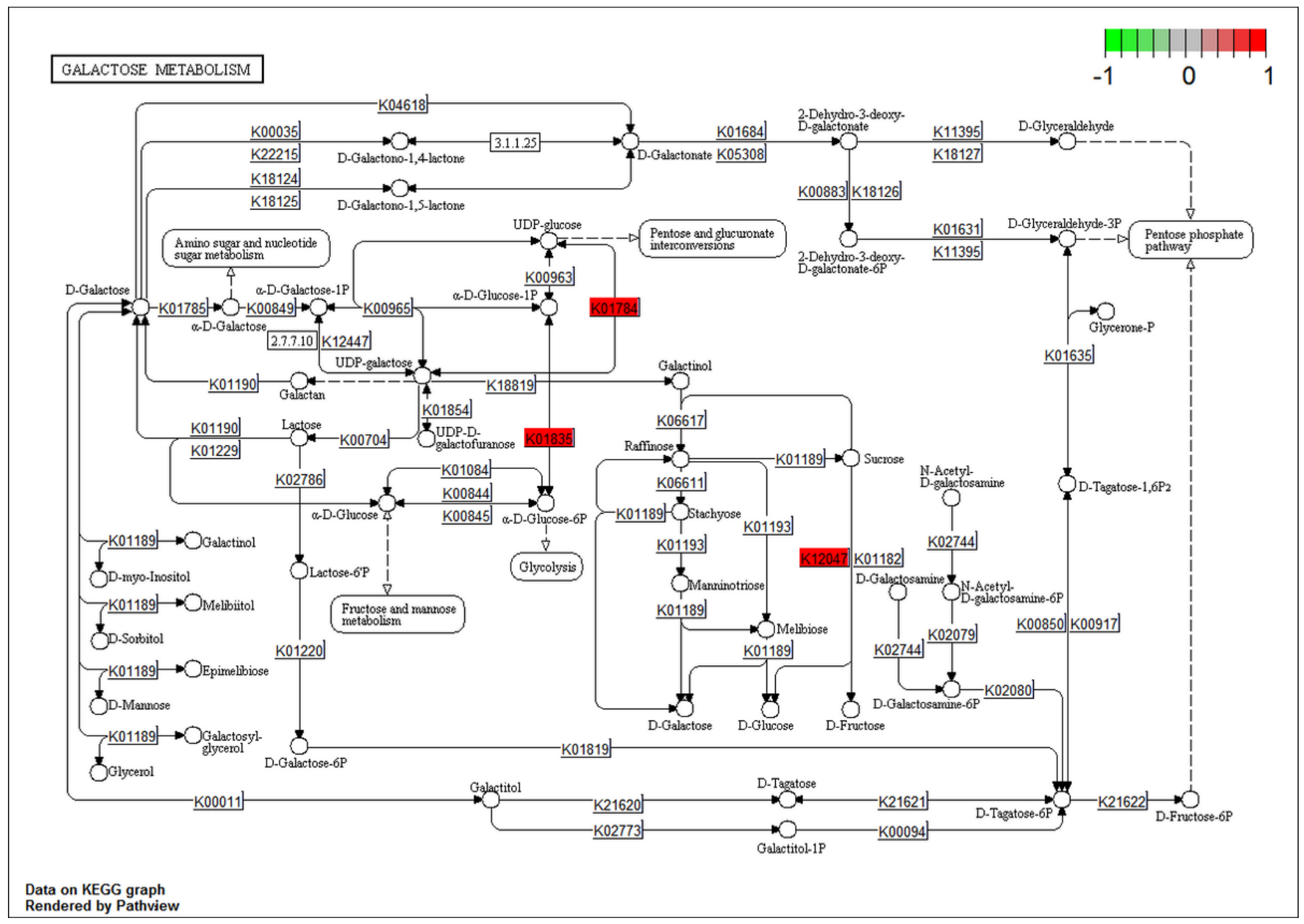

\section{Figure 7}

Galactose metabolic pathways and differences in expression under the $\mathrm{ONH}$ vs ANH conditions. The color legend in the upper right corner indicates red values for level of gene upregulation and green for gene downregulation, as indicated for differentially expressed genes within the pathway map. 
TAURINE AND HYPOTAURINE METABOLISM
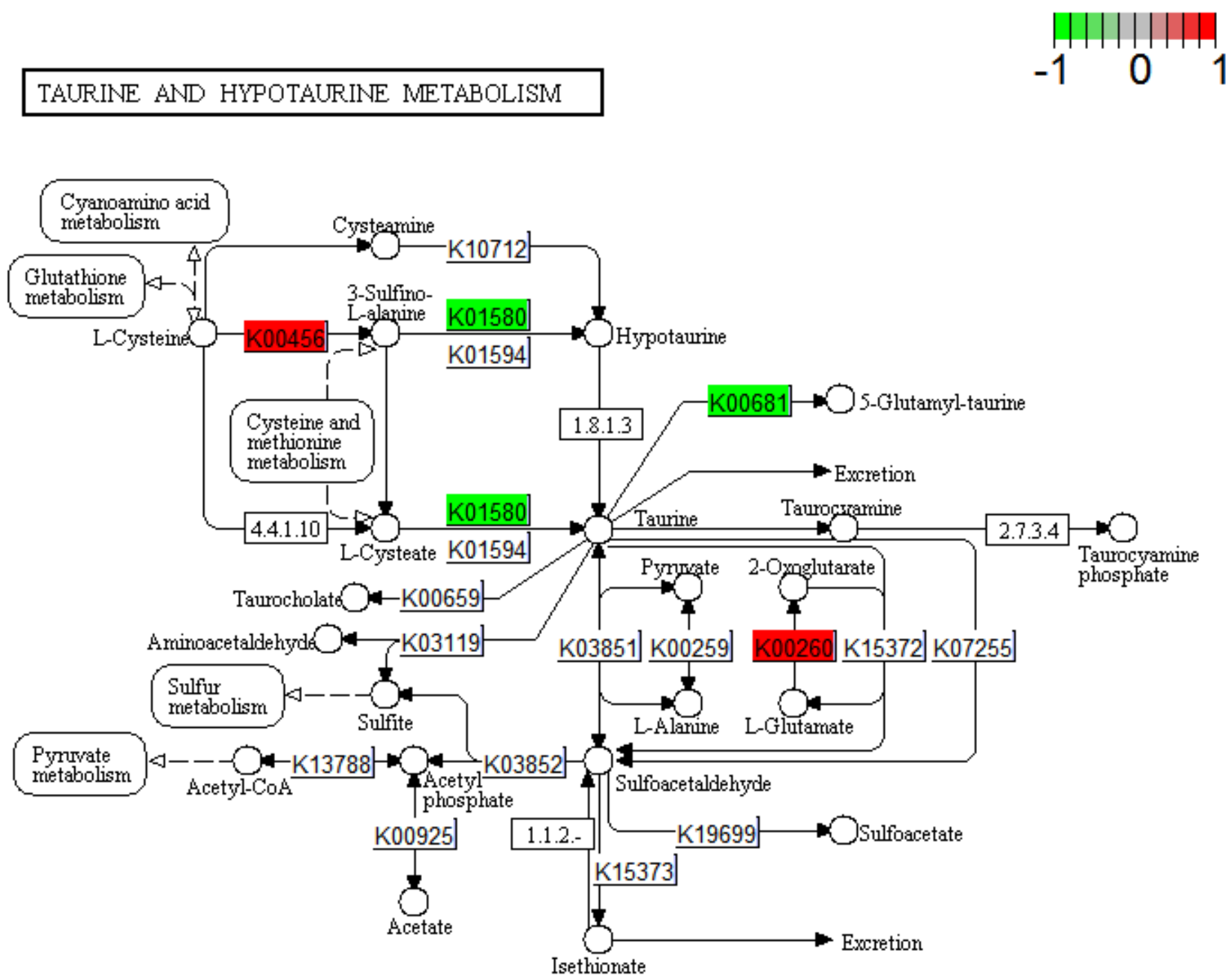

Data on KEGG graph

Rendered by Pathview

Figure 8

Taurine and hypotaurine metabolic pathways and differences in expression under the ONH vs ANH conditions. The color legend in the upper right corner indicates red values for level of gene upregulation and green for gene downregulation, as indicated for differentially expressed genes within the pathway map. 


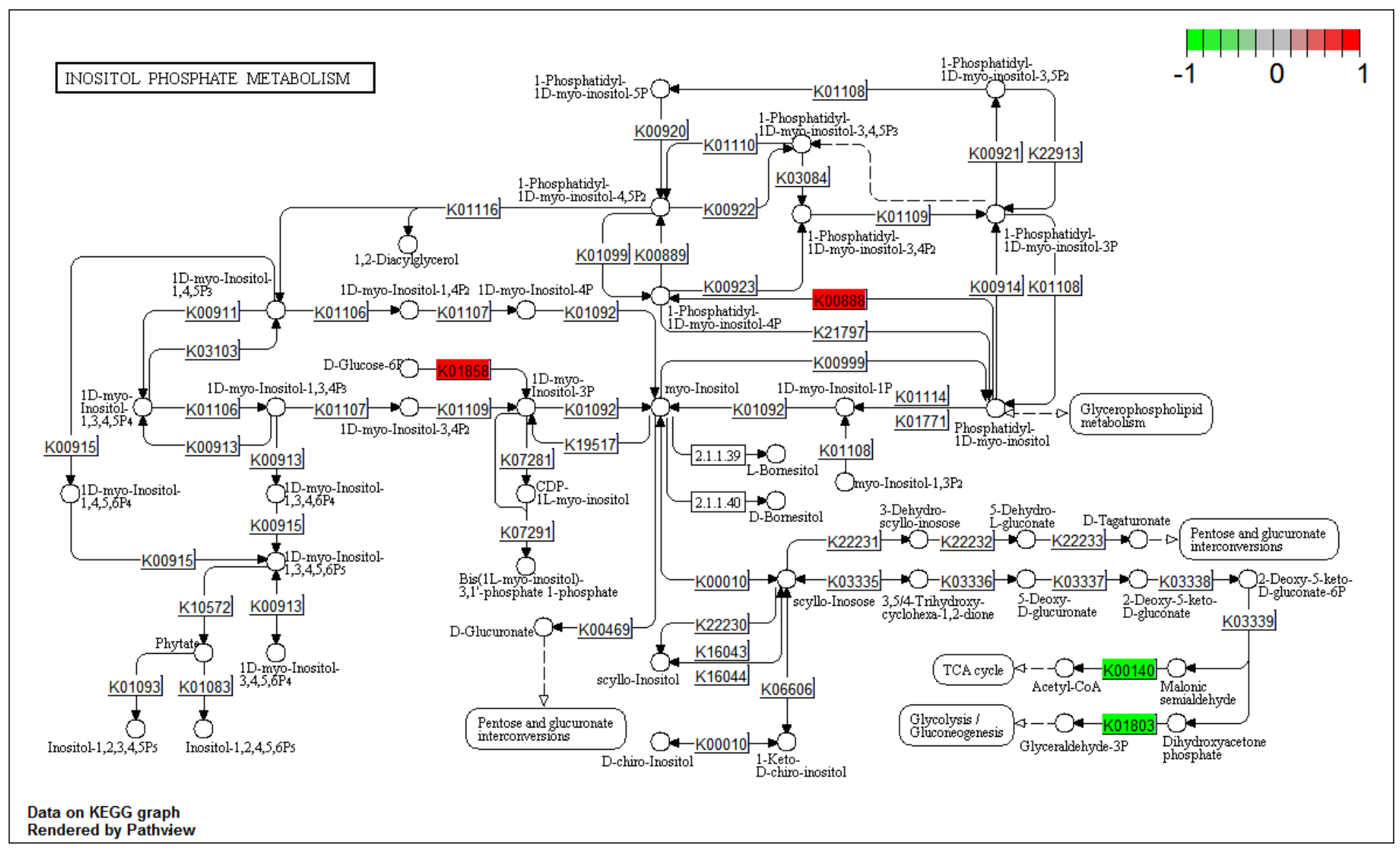

Figure 9

Inositol phosphate metabolic pathways and differences in expression under the $\mathrm{COH}$ vs $\mathrm{OOH}$ conditions. The color legend in the upper right corner indicates red values for level of gene upregulation and green for gene downregulation, as indicated for differentially expressed genes within the pathway map. 


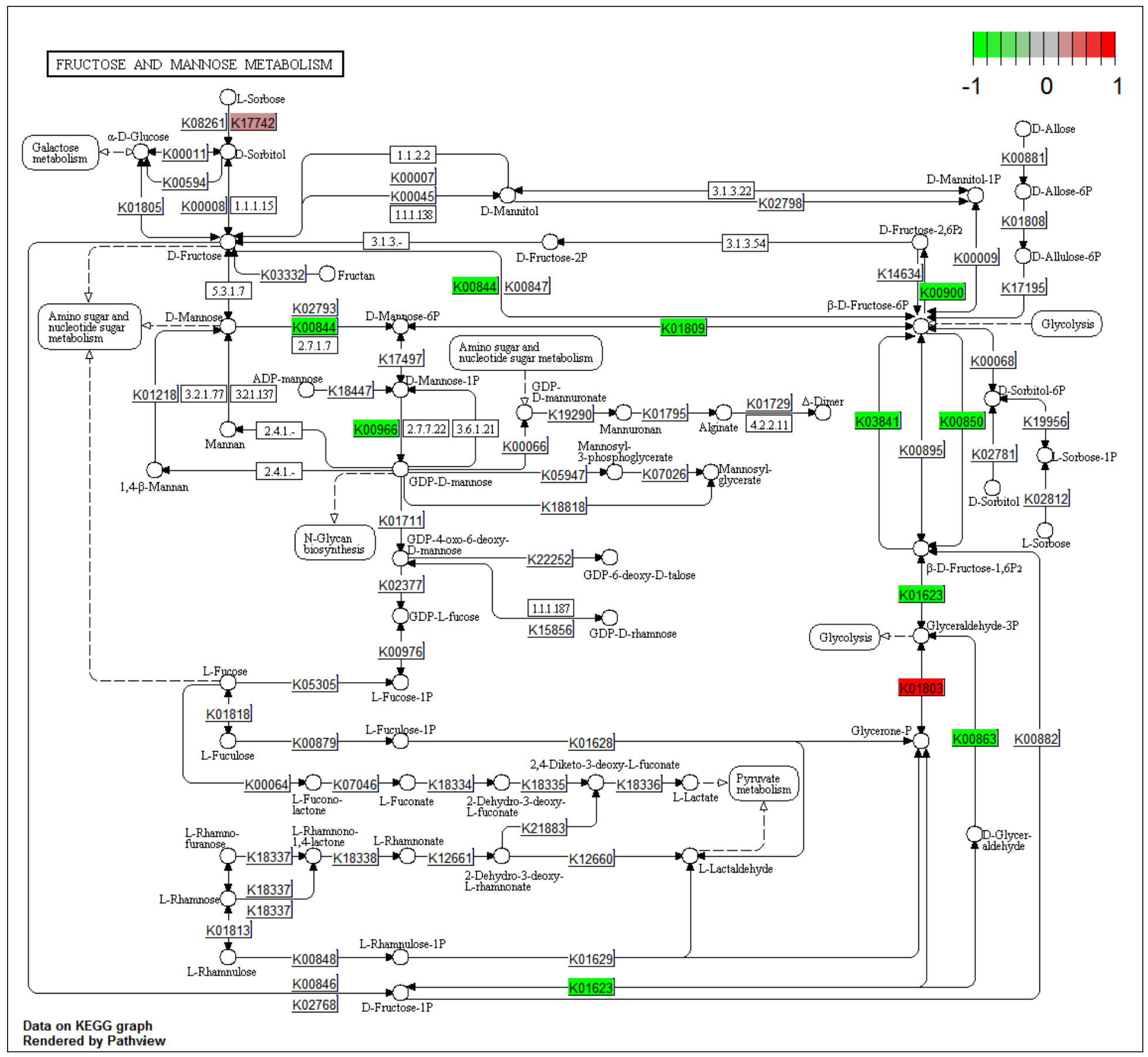

Figure 10

Fructose and mannose metabolic pathways and differences in expression under the $\mathrm{COH}$ vs $\mathrm{CNH}$ Conditions. The color legend in the upper right corner indicates red values for level of gene upregulation and green for gene downregulation, as indicated for differentially expressed genes within the pathway map. 


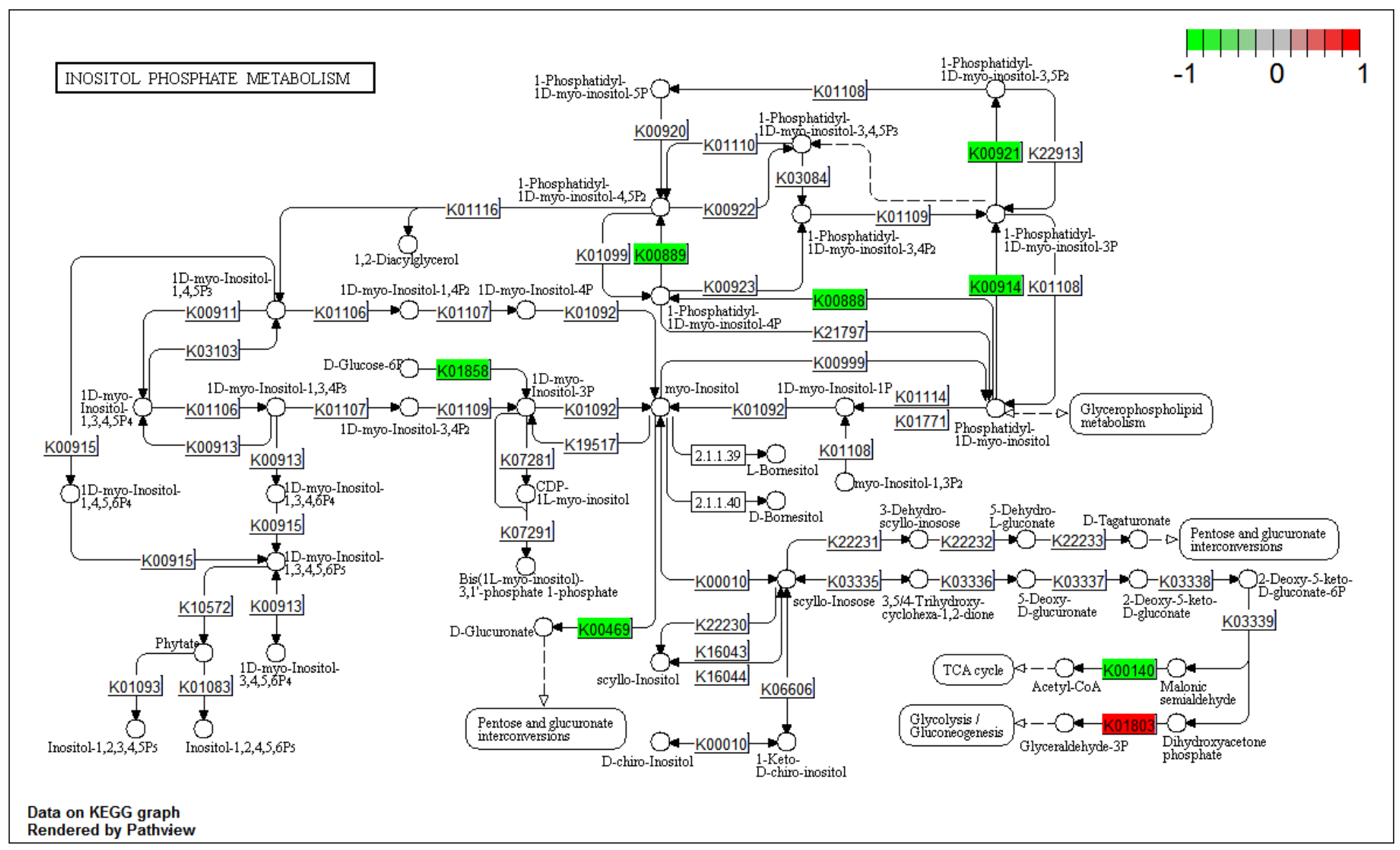

Figure 11

Inositol phosphate metabolic pathways and differences in expression under the $\mathrm{COH}$ vs $\mathrm{CNH}$ Conditions. The color legend in the upper right corner indicates red values for level of gene upregulation and green for gene downregulation, as indicated for differentially expressed genes within the pathway map. 